GUSTAVO LUÍS DA CRUZ HAICAL

\title{
A AUTORIZAÇÃO NO DIREITO PRIVADO
}

Tese de Doutorado

Orientador: Professor Dr. Alcides Tomasetti Júnior

UNIVERSIDADE DE SÃO PAULO

FACULDADE DE DIREITO

São Paulo - SP

2019 



\section{GUSTAVO LUÍS DA CRUZ HAICAL}

\section{A AUTORIZAÇÃO NO DIREITO PRIVADO}

Tese apresentada à banca examinadora do Programa de PósGraduação em Direito da Faculdade de Direito da Universidade de São Paulo, como exigência parcial para obtenção do título de Doutor em Direito na área de concentração Direito Civil, sob a orientação do Prof. Dr. Alcides Tomasetti Júnior.

UNIVERSIDADE DE SÃO PAULO

FACULDADE DE DIREITO

São Paulo - SP 
Serviço de Processos Técnicos da Biblioteca da

Faculdade de Direito da Universidade de São Paulo

Haical, Gustavo Luís da Cruz

A autorização no Direito Privado / Gustavo Luís da Cruz Haical. -- São Paulo, 2019.

188 p. $; 30 \mathrm{~cm}$.

Tese (Doutorado) - Programa de Pós-Graduação em Direito, Faculdade de Direito, Universidade de São Paulo, São Paulo, 2019.

Orientador: Alcides Tomasetti Júnior.

1. Negócio jurídico. 2. Assentimento. 3. Autorização. 4. Exercício jurídico e legitimidade. 5. Faculdade e poder de dispor. I. Tomasetti Júnior, Alcides, orient. II. Título. 
Defesa oral para a obtenção de título de Doutor em Direito realizada em de de 2019.

Banca examinadora composta pelos Professores: 

Ao Pontes de Miranda e

à Judith Martins-Costa - pelas lições.

À Milena Guerreiro, pelo incentivo.

Aos meus pais:

Maria Roselaine da Cruz Haical

e Celso Luiz Afonso Haical, pelo amor. 

"Não há ciência sem conceitos precisos; se eles faltam, o que se consulta, para julgar, é o sentimento, a equidade, o que mais parece ser justo. Ora, justiça que se funda em tais escapatórias, não é justiça".

Pontes de Miranda 



\section{AGRADECIMENTOS}

Esta tese não é resultado, apenas, de três anos de um curso de doutorado, mas de quase vinte anos de estudo e reflexão diários. Estudar, pensar e redigir este trabalho, conquanto tenha sido tarefa que me obrigou a um esforço solitário e obstinado representando também, muitas vezes, um vencer a mim mesmo -, não teria sido possível sem a colaboração de zelosos e caros companheiros. Estes agradecimentos, portanto, geram palavras que brotam não da razão, mas do coração.

Agradeço aos professores Ápio Cláudio de Lima Antunes (in memoriam), Mozart Victor Russomano (in memoriam), Alberto Rufino Rosa Rodrigues de Souza (in memoriam), Carlos Francisco Sica Diniz, Fábio Scherer de Moura, José Luís Marasco Cavalheiro Leite, Pedro Moacyr Perez da Silveira, Paulo Fernando do Couto Bispo e Sérgio Luís Wetzel de Mattos, que, durante a minha graduação, na cidade de Pelotas, no Rio Grande do Sul, me deram lições e incentivos. Destaco os nomes de José Carlos Pereira de Almeida (in memoriam) e Francisco de Paula Bermúdez Guedes, por me terem acompanhado de perto, entusiasmando-se e vibrando em todas as minhas fases profissionais e acadêmicas. Igualmente importantes nesse período e nos subsequentes são os colegas e amigos Guilherme Camargo Massaú e Rodrigo Ribeiro Duarte.

Os fundamentos da minha formação como acadêmico adquiri, no curso de mestrado da Universidade Federal do Rio Grande do Sul, convivendo e aprendendo com Almiro Regis Matos do Couto e Silva (in memoriam), Itiberê de Oliveira Castellano Rodrigues e Véra Maria Jacob Fradera.

Durante o curso de doutorado, nas Arcadas do Largo de São Francisco, recebi as imprescindíveis lições dos professores Juliana Krueger Pela, Sheila Christina Neder Cerezetti, Otavio Luiz Rodrigues Junior, Erasmo Valladão Azevedo e Novaes França, Cristiano de Souza Zanetti, Francisco Paulo De Crescenzo Marino, Fernando Campos Scaff e Marco Fábio Morsello. Ao longo desse período, tive a felicidade de estabelecer ou de intensificar laços de amizade com Ana Maria Blanco, Ana Carolina Devitto Dearo Zanetti, André Rodrigues Correa, Augusto Cézar Lukascheck Prado, Bruno Bastos Becker, Cássio Cavalli, Clarissa Martins-Costa Loureiro-Chaves, Crisleine Barboza Yamaji, Éder Augusto Contadim, Edson Bonfim Soares, Eduardo Henrik Aubert, Eduardo Pinto de Almeida, Elizabeth da Rosa Conill, Fábio Floriano Melo Martins, Felipe Guaspari, Fernanda Mynarski Martins-Costa, Guilherme Teno Castilho Misale, Gustavo Stenzel 
Sanseverino, Giacomo Grezzana, Giovana Cunha Comiran, Giovana Valentiniano Benetti, Isadora Ribeiro, João Pedro Biazi, João Pedro Scalzilli, Jorge Cesa Ferreira da Silva, Laura Coradini Frantz, Laura Manuela Simões Silveira, Luis Felipe Spinelli, Luis Renato Ferreira da Silva, Marcel Edvar Simões, Mariana Martins-Costa Ferreira, Marta Marques Ávila, Matteo Rota Chiarelli, Osny da Silva Filho, Pedro Henrique Quitete Barreto, Pedro Luiz Brum Fickel, Pietro Benedetti Teixeira Webber, Renata Carlos Steiner, Regis da Silva Conrado, Rodrigo Tellechea, Rodrigo Xavier Leonardo e Vitor Vieira. Por uma palavra de incentivo, ou auxílio na pesquisa, ou lendo algum capítulo da tese, cada um deles contribuiu para tornar a jornada mais leve.

Conquanto todos tenham sido importantes, alguns foram essenciais para que eu chegasse ao fim desta jornada. A estes faço um agradecimento especial.

Ao meu orientador, Professor Alcides Tomasetti Júnior, que confiou em meu projeto e me orientou de forma segura e generosa ao longo de toda a tese. Estas palavras estendem-se à sua mulher, Professora Maria Bernadette Mercadante Neves, pela atenção e fidalguia com que me abriu as portas de sua casa.

A Rafael Branco Xavier, Guilherme Carneiro Monteiro Nitschke, Julio Gonzaga Andrade Neves e Eduardo Francisco de Souza, com os quais compartilho reflexões e ideais, por terem dedicado horas de suas vidas a revisar esta tese.

Ao amigo e colega Francisco Sabadin Medina, dotado de invulgar cultura jurídica, que colaborou incansavelmente para a elaboração desta tese. Levantou dúvidas, propôs reflexões e, assim, me permitiu aprofundar pensamentos, refinar conclusões e construir o texto com menos incertezas.

À Professora Judith Martins-Costa — de quem há pelo menos treze anos venho recebendo as maiores e as melhores lições acerca do que significam os papéis do professor e do jurista - agradeço pela confiança, pelas oportunidades profissionais que me ofereceu e pela grande amizade. Estendo este agradecimento ao Professor Miguel Reale Júnior, exemplo de jurista e homem público, pelo generoso incentivo ao meu crescimento intelectual.

À Milena Guerreiro, que me mostrou ser possível, sim, o sonho de cursar o doutorado nas Arcadas do Largo de São Francisco. Suas palavras foram fachos de luz que afastaram as minhas dúvidas, combateram as minhas inseguranças e me fizeram acreditar que meus horizontes profissionais eram maiores do que eu pensava. Por isso, e muito mais, sou-lhe eternamente grato. 
Agradeço ao meu irmão, Rafael da Cruz Haical, pela amizade, pelo carinho que nutrimos um pelo outro e pelo incentivo nas horas mais difíceis.

Agradeço à minha mãe, Maria Roselaine da Cruz Haical, que, com o seu amor incondicional, me transmitiu, na candura do seu silêncio, o conforto tão necessário para que eu perseverasse na minha caminhada.

Agradeço ao meu pai, Celso Luiz Afonso Haical, por me ter passado os valores da honestidade e da responsabilidade na vida familiar, social e profissional. Muito embora nunca tenha sido professor, soube ensinar-me, com o seu exemplo no escritório, que, sem livros, estudo e reflexão, não se forma um advogado, muito menos um acadêmico. De meu pai recebi duas lições fundamentais. A primeira: estudar a Parte Geral do Código Civil, por lá estarem os conceitos fundamentais do Direito Privado. A segunda: estudar Direito Privado a partir dos ensinamentos de Pontes de Miranda - que se tornou então o meu mestre e o meu autor. Sem a sua doutrina não teriam sido possíveis as condicionantes para um pensamento lógico e sistemático na análise do Direito Privado.

Agradeço, por fim, aos espíritos de luz: de um plano superior, estão sempre a me acompanhar, iluminando a minha jornada. 



\section{RESUMO}

Haical, Gustavo Luís da Cruz. A autorização no direito privado. 188 páginas. Doutorado. Faculdade de Direito. São Paulo: Universidade de São Paulo, 2019.

A presente tese intenta revelar a figura jurídica da autorização no direito privado brasileiro. Após expor a indeterminação do significado da palavra autorização no direito privado, a metodologia para a sua interpretação e a delimitação de seu significado, formulam-se o problema e as hipóteses para a construção da tese. Esta se distribui em dois parágrafos. No primeiro, com suporte nos artigos 176 e 220 do Código Civil e nos conceitos de figurante, parte e terceiro, insertos na teoria geral do negócio jurídico, identifica-se a autorização como espécie de assentimento prévio, por ser a declaração de vontade prestada por terceiro, não figurante, como elemento complementar à validade ou à eficácia de um negócio jurídico. Após desenvolver os elementos a compor a teoria geral do assentimento, conclui-se a primeira parte da tese com uma síntese das dogmáticas alemã e italiana sobre a figura da autorização, as quais serviram de fundamento para se reconhecerem, no sistema jurídico brasileiro, tanto a autorização integrativa como a autorização para dispor. No segundo parágrafo, pela análise dos conceitos de exercício jurídico e de legitimidade, examina-se cada uma das espécies de autorização. A autorização integrativa é delimitada como figura jurídica autônoma, classificada como negócio jurídico unilateral quanto a seus elementos de existência, validade e eficácia, bem como à sua extinção. Distingue-se, pois, da figura da permissão. Após analisar as regras jurídicas que justificam a existência da autorização para dispor, no sistema jurídico brasileiro, ela passa a ser delimitada como negócio jurídico unilateral quanto a seus elementos de existência, validade e eficácia, bem como à sua extinção. Ao final, apresentam-se os argumentos que inadmitem, no sistema jurídico interno, a existência das autorizações para cobrança, para contrair obrigação e para adquirir.

Palavras-Chave: 1. Negócio jurídico. 2. Assentimento. 3. Autorização. 4. Exercício jurídico e legitimidade. 5. Faculdade e poder de dispor 



\begin{abstract}
HAICAL, Gustavo Luís da Cruz. Authorization in private law. 188 pages. $\mathrm{PhD}$ degree. Law School. São Paulo, University of São Paulo, 2019.

This thesis seeks to reveal authorization as a legal institute in Brazilian private law. After discussing the indeterminate character of the word authorization in private law and the methodology of interpreting and restricting its legal meaning, the problem and hypotheses for the investigation are formulated. The thesis is divided into two paragraphs. In the first, authorization is identified as a kind of prior assent, since it is a declaration of will rendered by a third-party, who is not an 'interested party' which is a complementary element to the validity or efficacy of a legal transaction. This is supported by articles 176 and 220 of the Civil Code as well as the concepts of interested party (figurante), party, and third party inserted in the general theory of legal transaction. After developing the elements that compose the general theory of assent, the first part of the thesis is concluded with a synthesis of German and Italian legal doctrines of authorization, which served as a basis for recognizing both integrative authorization and the authorization to dispose in the Brazilian legal system. In the second paragraph, through an analysis of the concepts of legal exercise and legitimacy, each type of authorization is examined. Integrative authorization is defined as an autonomous legal institute, classified as a unilateral legal transaction as to its elements of existence, validity and efficacy, as well as to its termination. Therefore, integrative authorization is distinguished from the concept of permission. After analyzing legal rules that justify the existence of the authorization to dispose in the Brazilian legal system, authorization to dispose is defined as a unilateral legal transaction as to its elements of existence, validity and efficacy, as well as to its termination. At the end of the thesis, arguments that do not accept the existence of authorization to charge, authorization to enter into obligation and authorization to acquire in the internal legal system are discussed.
\end{abstract}

Keywords: 1. Legal transaction. 2. Assent. 3. Authorization. 4. Legal exercise and legitimacy. 5. Faculty and the right to dispose 



\section{RIASSUNTO}

Haical, Gustavo Luís da Cruz. L'autorizzazione nel diritto privato. 188 pagine. Dottorato di ricerca. Facoltà di Giurisprudenza. São Paulo: Università di São Paulo, 2019.

La presente tesi di dottorato intende rivelare la figura giuridica dell'autorizzazione nel diritto privato brasiliano. Dopo aver esposto l'indeterminatezza del significato della parola autorizzazione nel diritto privato, la metodologia per la sua interpretazione e la delimitazione del suo significato, vengono formulati il problema e le ipotesi per la costruzione della tesi. Questa si distribuisce in due paragrafi. Nel primo, con il supporto degli articoli 176 e 220 del codice civile e dei concetti di figurante, parte e terzo, inseriti nella teoria generale del negozio giuridico, l'autorizzazione è identificata come una sorta di assenso preventivo, essendo la dichiarazione di volontà espressa da un terzo, non figurante, come un elemento complementare alla validità o all'efficacia di un negozio giuridico. Dopo aver sviluppato gli elementi per comporre la teoria generale dell'assenso, la prima parte della tesi viene conclusa con una sintesi delle dogmatiche tedesca e italiana sulla figura dell'autorizzazione, le quali hanno fornito le basi perché siano riconosciuti, nel sistema giuridico brasiliano, tanto l'autorizzazione integrativa quanto l'autorizzazione a disporre. Nel secondo paragrafo, dall'analisi dei concetti di esercizio giuridico e di legittimità, viene esaminato ogni tipo di autorizzazione. L'autorizzazione integrativa è delimitata come figura giuridica autonoma, classificata come negozio giuridico unilaterale riguardo ai suoi elementi di esistenza, validità ed efficacia, così come alla sua estinzione. Viene distinta, pertanto, dalla figura del permesso. Dopo aver analizzato le norme giuridiche che giustificano l'esistenza dell'autorizzazione a disporre, nel sistema giuridico brasiliano, questa passa ad essere delimitata come un negozio giuridico unilaterale riguardo ai suoi elementi di esistenza, validità ed efficacia, così come alla sua estinzione. Alla fine vengono presentati gli argomenti che non ammettono, nel sistema giuridico interno, l'esistenza delle autorizzazioni a incassare, a contrarre l'obbligazione e ad acquisire.

Parole-Chiave: 1. Negozio giuridico. 2. Assenso. 3. Autorizzazione. 4. Esercizio giuridico e legittimità. 5. Facoltà e potere di disporre 



\section{SUMÁRIO}

INTRODUÇÃO

$\S 1^{\circ}$. A AUTORIZAÇÃo COMO FIGURA PERTENCENTE À TEORIA GERAL DO ASSENTIMENTO NO DIREITO PRIVADO

1. Os artigos 176 e 220 do Código Civil: suportes fáticos específicos para construir o significado da autorização

1.1. Parte e terceiro: conceitos necessários para se distinguir a autorização da confirmação

1.2. Suporte fático do negócio jurídico com atuação do terceiro assentinte 51

2. Da autorização de terceiro como elemento complementar de validade ou de eficácia do negócio jurídico 57

3. A teoria geral do assentimento no Código Civil brasileiro.

3.1. O assentimento à proteção de interesses jurídicos ..................................................... 74

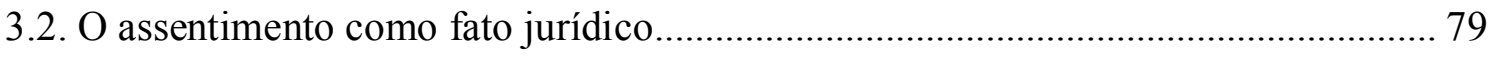

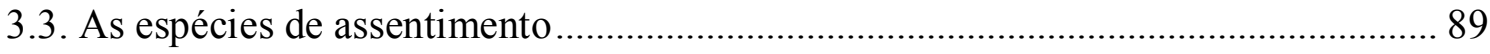

4. A autorização nas dogmáticas alemã e italiana: fundamentos dogmáticos à construção da autorização no sistema jurídico interno .................................................... 93

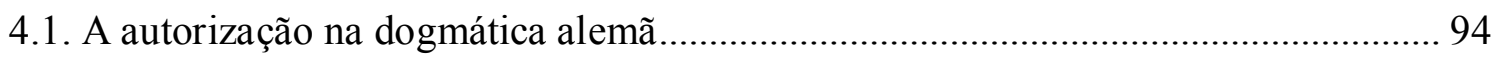

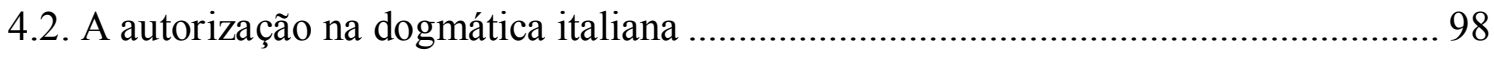

4.3. Hipóteses passíveis de serem dessumidas da doutrina alemã e italiana à construção

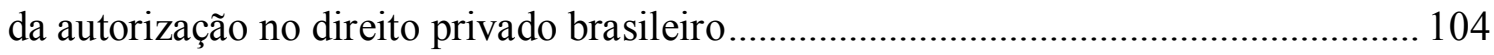

$\S 2^{\circ}$. A AUTORIZAÇÃO NO DIREITO PRIVADO BRASILEIRO .......................... 105

1. Exercício jurídico e legitimidade........................................................................................................ 106 
2.1. A autorização integrativa: sua delimitação como figura jurídica autônoma ............116

2.2. A autorização integrativa como negócio jurídico unilateral.....................................118

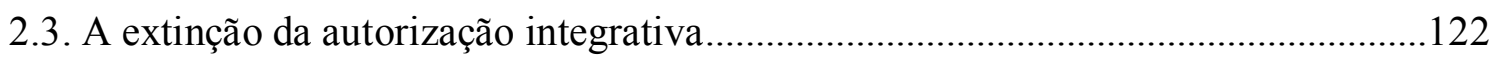

2.4. A permissão como figura jurídica distinta da autorização integrativa......................126

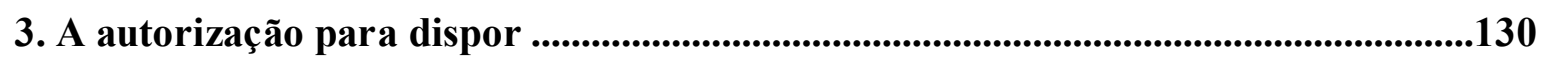

3.1. O fundamento legal para se dessumir a autorização para dispor no Código Civil..130

3.2. A autorização para dispor: delimitação como figura jurídica autônoma ..................138

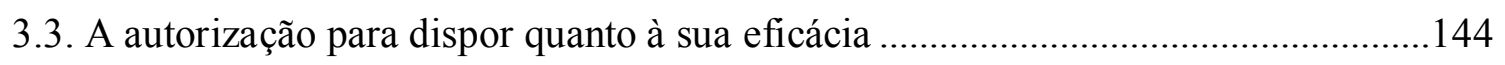

3.4. A autorização para dispor como negócio jurídico unilateral ....................................151

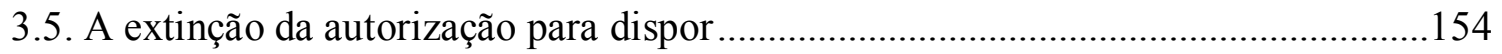

3.6. A autorização para cobrança, autorização para contrair obrigação e autorização para adquirir: figuras jurídicas inadmitidas no direito brasileiro a partir da autorização para dispor

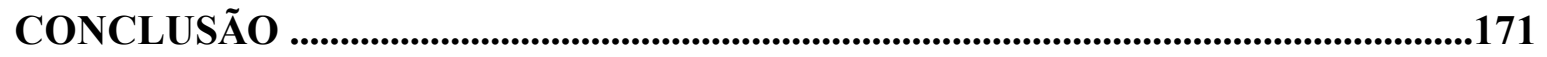

BIBLIOGRAFIA ................................................................................................................................173 


\title{
INTRODUÇÃO
}

\author{
"Interpretar lei não é só criticá-la: é \\ inserir-se nela, e fazê-la viver"
}

Pontes de Miranda

A lei escrita é um importante e insubstituível marco para o estado democrático de direito, por estabelecer as regras e princípios a compor o ordenamento jurídico. Por seu intermédio dá-se forma consistente às ideias jurídicas a comunicar ${ }^{1}$ ao grupo social a ela vinculado, conferindo-lhe, assim, segurança jurídica. ${ }^{2}$

O teor literal de uma norma ${ }^{3}$ é composto por elementos lógicos de linguagem: as palavras - signos ou sinais de notação. ${ }^{4} \mathrm{O}$ texto normativo e a linguagem técnico- jurídica são criados com as palavras da linguagem comum. ${ }^{5}$ Muito embora a linguagem técnicojurídica seja refém da linguagem comum, ${ }^{6}$ não se pode afirmar que a primeira seja constituída pelas palavras compósitas da segunda, sem nada a lhes acrescentar. ${ }^{7}$ Ao recolher palavras da linguagem comum para constituir a linguagem jurídica, o legislador em muitas delas imprime um significado jurídico. ${ }^{8}$ A linguagem jurídica exige mais

\footnotetext{
${ }^{1}$ KAUFMANN, Arthur. Filosofia do direito. Trad. António Ulisses Cortês. 5. ed. Lisboa: Calouste Gulbenkian, 2014, p. 182-183. ZIPPELIUS, Reinhold. Teoria do método jurídico. Trad. António Franco e António Francisco de Sousa. 11. ed. São Paulo: Saraiva, 2016, p. 46. Nesse sentido: MAXIMILIANO, Carlos. Hermenêtica e aplicação do direito. 3. ed. Rio de Janeiro: Freitas Bastos, 1941, § 118, p. 150.

${ }^{2}$ KAUFMANN, Arthur. Filosofia do direito. Trad. António Ulisses Cortês. 5. ed. Lisboa: Calouste Gulbenkian, 2014, p. 177. COING, Helmut. Elementos fundamentais da filosofia do direito. Trad. Elisete Antoniuk. Porto Alegre: Sergio Antonio Fabris, 2002, p. 186. ZIPPELIUS, Reinhold. Teoria do método jurídico. Trad. António Franco e António Francisco de Sousa. 11. ed. São Paulo: Saraiva, 2016, p. 45-46.

${ }^{3}$ KAUFMANN, Arthur. Filosofia do direito. Trad. António Ulisses Cortês. 5. ed. Lisboa: Calouste Gulbenkian, 2014, p. 177.

${ }^{4}$ ZIPPELIUS, Reinhold. Teoria do método jurídico. Trad. António Franco e António Francisco de Sousa. 11. ed. São Paulo: Saraiva, 2016, p. 46.

${ }^{5}$ KAUFMANN, Arthur. Filosofia do direito. Trad. António Ulisses Cortês. 5. ed. Lisboa: Calouste Gulbenkian, 2014, p. 142. COING, Helmut. Elementos fundamentais da filosofia do direito. Trad. Elisete Antoniuk. Porto Alegre: Sergio Antonio Fabris, 2002, p. 277. CARRIÓ, Genaro R. Notas sobre derecho y lenguaje. 3. ed. Buenos Aires: Abeledo-Perrot, 1986, p. 49. GRAU, Eros Roberto. Por que tenho medo dos juizes: a interpretação/aplicação do direito e os princípios. 6. ed. refundida do ensaio e discurso sobre a interpretação/aplicação do direito. São Paulo: Malheiros, 2013, p. 143. DÍEZ-PICAZO, Luis. Experiencias jurídicas y teoría del derecho. 3. ed. Barcelona: Ariel, 1993, p. 106.

${ }^{6}$ HAFT, Fritjof. Direito e linguagem. Introdução à filosofia do direito e à teoria do direito contemporâneas. Org. Arthur Kaufmann e Winfried Hassemer. Trad. Marcos Keel e Manuel Seca de Oliveira. Rev. e coord. António Manuel Hespanha. 3. ed. Lisboa: Calouste Gulbenkian, 2015, p. 319.

${ }^{7}$ KAUFMANN, Arthur. Filosofia do direito. Trad. António Ulisses Cortês. 5. ed. Lisboa: Calouste Gulbenkian, 2014, p. 143.

${ }^{8}$ KAUFMANN, Arthur. Filosofia do direito. Trad. António Ulisses Cortês. 5. ed. Lisboa: Calouste Gulbenkian, 2014, p. 143.
} 
precisão em seu significado, ${ }^{9}$ principalmente se empregada para designar termo técnico. ${ }^{10}$ A palavra "competência", por exemplo, não possui na linguagem jurídica o mesmo significado que na linguagem corrente. ${ }^{11}$

Ainda que o texto normativo apresente "clareza, precisão e ordem lógica", 12 as palavras selecionadas, valoradas e empregadas pelo legislador, têm precisão apenas relativa em seus significados, porquanto o sistema de sinais a compor a linguagem geral é limitado em face de uma realidade que é ilimitada. ${ }^{13}$ Não se dispõe de uma palavra para cada fato ou objeto a que se faz referência. ${ }^{14}$ As palavras apenas apreendem gênero ou classe. ${ }^{15-16}$

${ }^{9}$ LARENZ, Karl. Metodologia da ciência do direito. Trad. José Lamego. 3. ed. Lisboa: Calouste Gulbenkian, 1997, p. 280. "Os termos que exprimem o normativo cobram na linguagem da Jurisprudência um significado muito mais preciso do que o que têm na linguagem corrente geral".

${ }^{10}$ KAUFMANN, Arthur. Filosofia do direito. Trad. António Ulisses Cortês. 5. ed. Lisboa: Calouste Gulbenkian, 2014, p. 144.

${ }^{11}$ REALE, Miguel. Lições preliminares de direito. 24. ed. São Paulo: Saraiva, 1998, p. 8. "Às vezes, as expressões correntes, de uso comum do povo, adquirem, no mundo jurídico, um sentido técnico especial. Vejam, por exemplo, o que ocorre com a palavra 'competência' - adjetivo: competente. Quando dizemos que o juiz dos Feitos da Fazenda Municipal é competente para julgar as causas em que a Prefeitura é autora ou ré, não estamos absolutamente apreciando a 'competência' ou preparo cultural do magistrado. Competente é o juiz que, por força de dispositivos legais da organização judiciária, tem poder para examinar e resolver determinados casos, porque competência, juridicamente, é 'a medida ou a extensão da jurisdição"'.

${ }^{12} \mathrm{O}$ sistema jurídico brasileiro, para que o legislador promulgue leis dotadas de clareza, precisão e ordem lógica, fixou no art. 11 da Lei Complementar n. 95/1998 regras jurídicas de técnica legislativa para se alcançar cada um dos predicados indicados: "As disposições normativas serão redigidas com clareza, precisão e ordem lógica, observadas, para esse propósito, as seguintes normas: [...]".

${ }^{13}$ HAFT, Fritjof. Direito e linguagem. Introdução à filosofia do direito e à teoria do direito contemporâneas. Org. Arthur Kaufmann e Winfried Hassemer. Trad. Marcos Keel e Manuel Seca de Oliveira. Rev. e coord. António Manuel Hespanha. 3. ed. Lisboa: Calouste Gulbenkian, 2015, p. 310.

${ }^{14}$ PONTES DE MIRANDA, Francisco Cavalcanti. Sistema de ciência positiva do direito. Campinas: Bookseller, 2000, t. II, p. 101. CARRIÓ, Genaro R. Notas sobre derecho y lenguaje. 3. ed. Buenos Aires: Abeledo-Perrot, 1986, p. 27.

${ }^{15}$ PONTES DE MIRANDA, Francisco Cavalcanti. Sistema de ciência positiva do direito. Campinas: Bookseller, 2000, t. II, p. 101. "Seria, pois, de grande conveniência dar a cada objeto o respectivo sinal, como acontece em relação ao sol, à lua, a Vênus, Londres, Pascal; mas a infinidade dos objetos e a limitada capacidade do espírito humano tornam impossível tal processo equi-extensivo. À maioria deles apenas se dá o nome do gênero ou da classe: boi, homem, sujeito de direito; ou da coisa, qualidade ou relação análoga, e.g., azul-marinho, verde-garrafa, reivindicação de posse, iuris vinculum etc. Muitos, após a atuação histórica (hereditariedade individual e social, educação, técnica), conseguem exprimir novos objetos, mas só excepcionalmente se referem a coisas singulares e quase sempre a gêneros e a classes: obligatio, creditor, possessio, reivindicativo. Somente com elementos combinados é que podem ser expressas quase todas as coisas, qualidades, relações etc". CARRIÓ, Genaro R. Notas sobre derecho y lenguaje. 3. ed. Buenos Aires: Abeledo-Perrot, 1986, p. 27.

${ }^{16}$ Talvez por isso Pontes de Miranda tenha afirmado que "[a] linguagem mal disfarça o que é: amálgama de pedaços dos espíritos, que ficam lá fora, indiferentes ao passar das gerações, a despeito de banhá-las e arrancar-lhes vozes, ritmos e formas. Utiliza o que teve, o que tem e as significações com que ultrapassa a si mesma" (PONTES DE MIRANDA, Francisco Cavalcanti. Garra, mão e dedo. Campinas: Bookseller, 2002, p. 10). MAXIMILIANO, Carlos. Hermenêutica e aplicação do direito. 3. ed. Rio de Janeiro: Freitas Bastos, 1941, § 117, p. 149. "A letra não traduz a ideia, na sua integridade: provoca, em alheio cérebro, o abrolhar de um produto intelectual semelhante, jamais idêntico, ao que a fórmula é chamada a exprimir" [itálicos do autor]. 
Nessa perspectiva, a linguagem jurídica, por derivar da comum, também resta indeterminada quanto ao significado, ${ }^{17}$ sendo ilusória a sua rigidez. ${ }^{18}$ Tal indeterminação, contudo, não o é em termos absolutos, mas apenas em maior ou menor grau, ${ }^{19}$ porque toda palavra tem um núcleo de determinação ou significação. ${ }^{20}$ Para afastar a indeterminação de uma palavra a compor proposições e enunciados ${ }^{21}$ normativos, atribuindo-lhe significado ${ }^{22}$ sem violar o princípio da segurança jurídica e a unidade do sistema jurídico - e ainda permitir aplicar o significado aos casos similares - , deve o intérprete desenvolver uma argumentação racional fundada em metodologia jurídica. ${ }^{23-24}$

${ }^{17}$ COING, Helmut. Elementos fundamentais da filosofia do direito. Trad. Elisete Antoniuk. Porto Alegre: Sergio Antonio Fabris, 2002, p. 279. "Nos direitos que conhecemos até hoje, as regras jurídicas são formuladas na linguagem moderna. Com isto o direito conecta ao mesmo tempo conteúdos ideais, contidos na linguagem. Somente a partir destes, desde que necessário, o significado jurídico específico é desenvolvido. Este significado do idioma facilita primeiramente, a formulação das regras jurídicas; mas ele é duvidoso, porque o direito com isto também adere às imprecisões do idioma, e ele estreita o significado das regras jurídicas, porque ela sempre está atada a tradições linguísticas ou intelectuais de uma certa comunidade linguística". Nesse sentido: ENGISCH, Karl. Introdução ao pensamento jurídico. Trad. João Baptista Machado. 7. ed. Lisboa: Calouste Gulbenkian, 1996, p. 209. CARRIÓ, Genaro R. Notas sobre derecho y lenguaje. 3. ed. Buenos Aires: Abeledo-Perrot, 1986, p. 27. MAXIMILIANO, Carlos. Hermenêutica e aplicação do direito. 3. ed. Rio de Janeiro: Freitas Bastos, 1941, § 20, p. 31.

${ }^{18}$ MAXIMILIANO, Carlos. Hermenêutica e aplicação do direito. 3. ed. Rio de Janeiro: Freitas Bastos, 1941, $\S 20$, p. 31 .

${ }^{19}$ LUZZATI, Claudio. La vaghezza delle norme: un'analisi del linguaggio giuridico. Milano: Giuffrè, 1990, p. 4-5. CARRIÓ, Genaro R. Notas sobre derecho y lenguaje. 3. ed. Buenos Aires: Abeledo-Perrot, 1986, p. 53. MARTINS-COSTA, Judith. A boa-fé no direito privado: critérios para a sua aplicação. São Paulo: Marcial Pons, 2015, p. 133-134.

${ }^{20}$ Afirmar que uma palavra é indeterminada "não quer dizer que ela não tenha núcleo de significação, nem que não possa sofrer determinação pelo uso ou pelo próprio sistema no qual esteja inserida" (ÁVILA, Humberto. Teoria dos princípios: da definição à aplicação dos princípios jurídicos. 17. ed. São Paulo: Malheiros, 2016, p. 139). Nesse sentido: LUZZATI, Claudio. La vaghezza delle norme: un'analisi del linguaggio giuridico. Milano: Giuffrè, 1990, p. 69. LUMIA, Giuseppe. Lineamenti di teoria e ideologia del diritto. 3. ed. Milano: Giuffrè, 1981, p. 83.

${ }^{21}$ LUMIA, Giuseppe. Lineamenti di teoria e ideologia del diritto. 3. ed. Milano: Giuffrè, 1981, p. 40. "La norma giuridica - si tratti dell'articolo di una legge, del dispositivo di una sentenza o della clausola di un contratto - si presenta, sotto il profilo linguistico-formale, come una proposizione, ossia come una sequenza di parole dotata di significato. Dalle proposizioni vanno distinti gli enunciati, intendendosi per enunciato il complesso lessicale-sintattico dei segni linguistici con cui è espressa la preposizione".

${ }^{22}$ ÁVILA, Humberto. Teoria dos princípios: da definição à aplicação dos princípios jurídicos. 17. ed. São Paulo: Malheiros, 2016, p. 53-54. "Daí se dizer que interpretar é construir a partir de algo, por isso significa reconstruir: a uma, porque utiliza como ponto de partida os textos normativos, que oferecem limites à construção de sentidos; a duas, porque manipula à linguagem, à qual são incorporados núcleos de sentidos, que são, por assim dizer, constituídos pelo uso, e preexistem ao processo interpretativo individual" [itálicos do autor].

${ }^{23}$ ZIPPELIUS, Reinhold. Teoria do método jurídico. Trad. António Franco e António Francisco de Sousa. 11. ed. São Paulo: Saraiva, 2016, p. 34-35.

${ }^{24}$ A posição apresentada parte da ideia de que, aplicando-se uma argumentação racional, fundada na metódica jurídica, se alcance, dentro dos limites do sistema jurídico, uma interpretação admissível e justa. Se houver hipótese em que não seja possível ao interprete, por emprego dos métodos e da argumentação racional, alcançar uma interpretação admissível e justa, estará legitimado, a excepcionar o princípio da separação dos poderes e a segurança jurídica, para desenvolver a complementação ou correção da lei. À compreensão dessas questões: ZIPPELIUS, Reinhold. Teoria do método jurídico. Trad. António Franco e António Francisco de Sousa. 11. ed. São Paulo: Saraiva, 2016, p. 113-114 e 136 a 140. LARENZ, Karl. Metodologia da ciência do direito. Trad. José Lamego. 3. ed. Lisboa: Calouste Gulbenkian, 1997, p. 453454. 
A linguagem comum tem função primordial para a interpretação jurídica; traça os limites à atribuição de um significado na linguagem jurídica. ${ }^{25}$ Para conferir significado a uma palavra, o intérprete deverá trabalhar dentro do seu "quadro de estrutura linguística", e dentro do enunciado normativo a que ela pertence no sistema jurídico. ${ }^{26}$ Este quadro é tanto o ponto de partida da interpretação quanto a fonte delimitadora da atividade do intérprete. ${ }^{27}$ Ultrapassar o "sentido literal possível" 28 — imposto pela linguagem geral e pelos usos linguísticos — ${ }^{29}$ ao contrário de ser interpretação, ${ }^{30}$ é modificação do sentido do texto. ${ }^{31}$ É metodologicamente permitido apenas quando for hipótese de (i) integração de lacuna; ou de (ii) analogia; (iii) ou de redução teleológica. ${ }^{32}$ Ultrapassar o sentido literal possível sem argumentos coerentes e racionalmente controláveis significa, em sentido amplo, violar a separação de poderes, a igualdade de tratamento perante casos similares e a segurança jurídica. ${ }^{33-34-35}$ A essa autolimitação não está vinculado apenas o juiz, mas

${ }^{25}$ LARENZ, Karl. Metodologia da ciência do direito. Trad. José Lamego. 3. ed. Lisboa: Calouste Gulbenkian, 1997, p. 453.

${ }^{26}$ SCARPELLI, Uberto. Semantica giuridica. Novissimo digesto italiano. Torino: UTET, 1969, v. XVI, p. 997. "L'interprete opera, infatti, nel quadro di una struttura linguistica, sia pure a volte molto elastica, e, se intende mediante interpretazione condurre a compimento una comunicazione linguistica entro tale struttura, deve inserire le sue innovazioni nella struttura, può giocare nei suoi spazi, può magari violentarla, ma non può saltarne fuori del tutto". LUZZATI, Claudio. La vaghezza delle norme: un'analisi del linguaggio giuridico. Milano: Giuffrè, 1990, p. 69. GUASTINI, Riccardo. Interpretare e argomentare. Trattato di diritto civile e commerciale. Milano: Giuffrè, 2011, p. 59.

${ }^{27}$ LARENZ, Karl. Metodologia da ciência do direito. Trad. José Lamego. 3. ed. Lisboa: Calouste Gulbenkian, 1997, p. 457.

${ }^{28}$ LARENZ, Karl. Metodologia da ciência do direito. Trad. José Lamego. 3. ed. Lisboa: Calouste Gulbenkian, 1997, p. 454. "Por «sentido literal possível» entendo tudo aquilo que nos termos do uso linguístico que seja de considerar como determinante em concreto - mesmo que, porventura, em circunstâncias especiais - , pode ainda ser entendido como o que com esse termo se quer dizer".

${ }^{29}$ LUMIA, Giuseppe. Lineamenti di teoria e ideologia del diritto. 3. ed. Milano: Giuffrè, 1981, p. 86.

${ }^{30}$ GUASTINI, Riccardo. Interpretare e argomentare. Trattato di diritto civile e commerciale. Milano: Giuffrè, 2011, p. 61. 'Da questo punto di vista, deve intendersi per 'interpretazione' non qualsivoglia attribuzione di significato al testo interpretato, ma un'attribuzione di significato che ricada entro la cornice di variabilie ampiezza - dei significati ammissibili".

${ }^{31}$ LARENZ, Karl. Metodologia da ciência do direito. Trad. José Lamego. 3. ed. Lisboa: Calouste Gulbenkian, 1997, p. 453.

${ }^{32}$ LARENZ, Karl. Metodologia da ciência do direito. Trad. José Lamego. 3. ed. Lisboa: Calouste Gulbenkian, 1997, p. 454.

${ }^{33}$ ZIPPELIUS, Reinhold. Teoria do método jurídico. Trad. António Franco e António Francisco de Sousa. 11. ed. São Paulo: Saraiva, 2016, p. 34.

${ }^{34}$ REALE, Miguel. Fontes e modelos do direito: para um novo paradigma hermenêutico. São Paulo: Saraiva, 1999, p. 110. "Por mais que a interpretação possa tirar partido da elasticidade normativa, preenchendo os vazios inevitáveis do sistema, deve ela sempre manter compatibilidade lógica e ética com o ordenamento jurídico positivo, excluída a possibilidade, verbi gratia, de recusar-se eficácia a uma regra de Direito Positivo a pretexto de colisão com ditames de uma justiça natural ou de pesquisa sociológica. Não se pode, em suma, recusar eficácia às estruturas normativas objetivadas no processo concreto da história, sob pena de periclitar o valor da certeza jurídica, ao sabor de interpretações que refletem, não raro, posições subjetivas variáveis e incertas" [itálicos do autor]. Igualmente: MARTINS-COSTA, Judith. Autoridade e utilidade da doutrina: a construção dos modelos doutrinários. Modelos de direito privado. Org. Judith Martins-Costa. São Paulo: Marcial Pons, 2014, p. 28-29.

${ }^{35}$ Importa destacar que, nesse contexto, o princípio da segurança jurídica estará sendo violado em sua perspectiva relativa à segurança no direito. Conforme ensina Humberto Ávila, a segurança no direito "não 
também a doutrina que pretenda cumprir o seu mister de servir à aplicação do direito. ${ }^{36}$ Embora os modelos hermenêuticos doutrinários produzidos não sejam dotados de poder prescritivo, ${ }^{37}$ acabam por influir na formação conclusiva do aplicador da norma jurídica. ${ }^{38}$

Posteriormente ao método inicial de interpretação a partir do significado na linguagem comum, o segundo passo relativo refere-se à atribuição de significado conotado ao ramo do direito em que está inserida a palavra.

Para efetuar uma interpretação fundada no instrumental técnico-jurídico e atribuir significado ao texto normativo, o intérprete deve estar atento às regras do jogo de linguagem jurídica. ${ }^{39-40}$ Só assim efetuará uma interpretação que alcance um significado racional e faça sentido no sistema. ${ }^{41}$ Para cada ramo do direito há um jogo de linguagem específico, ${ }^{42}$ embora, a depender da palavra que se interpreta, esta possa apresentar núcleo de significação similar em mais de um jogo da linguagem. ${ }^{43}$ Saber jogar com a linguagem jurídica em hipótese alguma é fazer malabarismos com as palavras, interpretando-as ao talante do intérprete.

tem o seu núcleo na exigência de conhecimento de conteúdos total e previamente determinados, mas na controlabilidade de estruturas argumentativas exigidas na reconstrução e na aplicação de sentidos normativos. A segurança jurídica, em suma, revela-se no curso do processo de realização do Direito. Essa acepção - segurança no Direito - ilustra, com maior amplitude, o significado geral do princípio da segurança jurídica, que deixa de ser centrado no conhecimento prévio de efeitos jurídicos para passar a abranger, especialmente, a controlabilidade de processos argumentativos" [itálicos do autor] (ÁVILA, Humberto. Teoria da segurança jurídica. 4. ed. São Paulo: Malheiros, 2016, p. 275).

${ }^{36}$ ZIPPELIUS, Reinhold. Teoria do método jurídico. Trad. António Franco e António Francisco de Sousa. 11. ed. São Paulo: Saraiva, 2016, p. 34. "A autolimitação de uma dogmática que está ao serviço da aplicação do direito corresponde ao princípio da separação de poderes e serve ao mesmo tempo à igualdade de tratamento e à segurança jurídica".

${ }^{37}$ REALE, Miguel. Fontes e modelos do direito: para um novo paradigma hermenêutico. São Paulo: Saraiva, 1999, p. 107. MARTINS-COSTA, Judith. Autoridade e utilidade da doutrina: a construção dos modelos doutrinários. Modelos de direito privado. Org. Judith Martins-Costa. São Paulo: Marcial Pons, 2014, p. 27.

${ }^{38}$ LUMIA, Giuseppe. Lineamenti di teoria e ideologia del diritto. 3. ed. Milano: Giuffrè, 1981, p. 84-85. MARTINS-COSTA, Judith. Autoridade e utilidade da doutrina: a construção dos modelos doutrinários. Modelos de direito privado. Org. Judith Martins-Costa. São Paulo: Marcial Pons, 2014, p. 16-17.

39 LARENZ, Karl. Metodologia da ciência do direito. Trad. José Lamego. 3. ed. Lisboa: Calouste Gulbenkian, 1997, p. 280.

40 A expressão "jogo de linguagem" remete à obra Investigações Filosóficas, de autoria de Ludwig Wittgenstein. A expressão é empregada para, em síntese, dispor que, antes de se buscar compreender o significado de uma palavra, se deve buscar compreender como funciona e como é empregada a linguagem em que está inserta a palavra, ou seja, saber conhecer as "regras do jogo" em que está inserida a palavra. O fundamental da linguagem como jogo é saber usá-la. Sobre jogos da linguagem: MORA, José Ferreter. Diccionario de filosofia. 3. ed. Madrid: Alianza, 1981, t. 3, p. 1944-1945.

${ }^{41}$ LARENZ, Karl. Metodologia da ciência do direito. Trad. José Lamego. 3. ed. Lisboa: Calouste Gulbenkian, 1997, p. 279. "Temos de ter assim em conta, de modo muito preciso, em que sentido é que se usa um termo, para que não se «saia» de modo inconsciente de um jogo de linguagem, o que significa sempre confusão de conceitos".

${ }^{42}$ LARENZ, Karl. Metodologia da ciência do direito. Trad. José Lamego. 3. ed. Lisboa: Calouste Gulbenkian, 1997, p. 279.

43 LARENZ, Karl. Metodologia da ciência do direito. Trad. José Lamego. 3. ed. Lisboa: Calouste Gulbenkian, 1997, p. 278-279. 
É preciso, portanto, estarmos certos de que a linguagem a compor o mundo jurídico o transforma em objeto sobre o qual se fala e se interpreta, sendo este objeto, em verdade, o direito vigente em seu sentido normativo. ${ }^{44}$ Assim, o significado da palavra na linguagem jurídica, partindo do significado na linguagem comum, será obtido a partir da interpretação do enunciado em que é parte integrante e em relação aos enunciados que lhe são conexos ou opostos ${ }^{45}$, bem como do ramo do direito em que está inserido o enunciado. ${ }^{46}$

Sem esquecermos a metódica jurídica apresentada, constata-se, ao lermos o Código Civil, a existência de muitas palavras de elevada indeterminação, apresentando-se difíceis quanto à identificação e à delimitação de seu respectivo significado jurídico. Entre as palavras dotadas desse cariz está a palavra "autorização". Tanto é verdade que J. X. Carvalho de Mendonça asseverou: “A palavra autorização não tem sentido preciso no direito civil e comercial". ${ }^{47}$

Sendo a linguagem jurídica formada por palavras compósitas da linguagem comum, importa atentarmos para o significado da palavra "autorização" na segunda espécie de linguagem - e isto para que se possa revelar e indicar o caminho para se alcançar o significado jurídico que ela apreende na linguagem jurídica do direito privado.

\footnotetext{
${ }^{44}$ LARENZ, Karl. Metodologia da ciência do direito. Trad. José Lamego. 3. ed. Lisboa: Calouste Gulbenkian, 1997, p. 280-281: “A expressão «jogo da linguagem» não pode ser incorrectamente compreendida, como se se aludisse com ela simplesmente a um jogo com a linguagem, a um «fazer malabarismos» com palavras. Um jogo de linguagem, tal como aqui deve ser entendido, é o modo especial como - adentro de uma determinada linguagem - se fala de determinado sector de coisas ou âmbito de experiência. Tais sectores são, por exemplo, a natureza inanimada e a natureza viva, a técnica, a arte, ou mesmo o Direito. Numa linguagem, fala-se sobre algo. A compreensão por intermédio da linguagem é compreensão de uma coisa que é «trazida à linguagem». A coisa de que se fala na linguagem normativa da Jurisprudência é a «coisa do direito». À pergunta sobre o que seja esta «coisa Direito» deve responder-se, na minha opinião, do seguinte modo: é o «Direito vigente», no seu sentido normativo, precisamente enquanto «Direito»”. Nesse sentido: GRAU, Eros Roberto. Por que tenho medo dos juízes: a interpretação/aplicação do direito e os princípios. 6. ed. refundida do ensaio e discurso sobre a interpretação/aplicação do direito. São Paulo: Malheiros, 2013, p. 145. ÁVILA, Humberto. Teoria dos princípios: da definição à aplicação dos princípios jurídicos. 17. ed. São Paulo: Malheiros, 2016, p. 52.

${ }^{45}$ LARENZ, Karl. Metodologia da ciência do direito. Trad. José Lamego. 3. ed. Lisboa: Calouste Gulbenkian, 1997, p. 280. ENGISCH, Karl. Introdução ao pensamento jurídico. Trad. João Baptista Machado. 7. ed. Lisboa: Calouste Gulbenkian, 1996, p. 259, nota 3. CARRIÓ, Genaro R. Notas sobre derecho y lenguaje. 3. ed. Buenos Aires: Abeledo-Perrot, 1986, p. 29.

${ }^{46}$ KAUFMANN, Arthur. Filosofia do direito. Trad. António Ulisses Cortês. 5. ed. Lisboa: Calouste Gulbenkian, 2014, p. 145.

${ }^{47}$ CARVALHO DE MENDONÇA, José Xavier. Tratado de direito commercial brasileiro. 2. ed. rev. por Achilles Bevilaqua e Roberto Carvalho de Mendonça. Rio de Janeiro: Freitas Bastos, 1934, v. VI, parte I, p. 200, nota 2. No mesmo sentido foi a afirmação de Angelo Nattini, no ano de 1912, ao abordar o tema, em primazia, no Direito Civil italiano: "Nel linguaggio giuridico la parola autorizzazione è usata di frequente ma con un significato amplissimo, impreciso, privo di contenuto" (NATTINI, Angelo. Il negozio autorizzativo. Rivista del diritto commerciale e del diritto generale delle obbligazioni. Milano: Dottor Francesco Vallardi, 1912, v. X, parte prima, p. 485).
} 
“Autorizar" é palavra originada do latim medieval auctorizare, ${ }^{48}$ authorizare ${ }^{49}$ — verbo derivado da sufixação de "autor" + "-izar", 50 significando "dar ou conferir autoridade"; 51 "dar autorização"; 52 "permitir"; 53 "adquirir autoridade, apoiar-se em um direito ou pretexto para fazer algo". ${ }^{54}$ Consequentemente, autorizado é quem está dotado de autoridade, ${ }^{55}$ sendo autorizador aquele que dá autoridade. ${ }^{56}$

“Autoridade" é palavra de origem latina derivada do latim auctoritas; 57 - 58 auctoritatem, ${ }^{59}$ as quais decorrem de auctor, ou seja, aquele que está investido do poder de autorizar. ${ }^{60} E$ a superioridade legal, fundada em lei divina positiva, ou humana, ou da opinião que, sendo dotada de força para se fazer respeitar e obedecer, configura poder, originando a potestade. ${ }^{61}$ Portanto, autoridade é pessoa revestida de poder; de direito. ${ }^{62}$

${ }^{48}$ HOUAISS, Antonio; VILLAR, Mauro de Salles. Dicionário Houaiss da língua portuguesa. Rio de Janeiro: Objetiva, 2009, p. 226.

${ }^{49}$ SILVA, Antonio de Moraes. Diccionario da lingua portugueza. 8. ed. Rio de Janeiro: Empreza Litteraria Fluminense, 1889, v. I, p. 284.

${ }^{50}$ FREIRE, Laudelino. Grande e novíssimo dicionário da língua portuguesa. 2. ed. Rio de Janeiro: José Olympio, 1954, v. I, p. 894. BUENO, Francisco da Silveira. Grande dicionário etimológico-prosódico da língua portuguesa. Saraiva: São Paulo, 1963, v. 1, p. 445. PRADO E SILVA, Adalberto et al. Dicionário brasileiro da língua portuguesa. 2. ed. São Paulo: Mirador Internacional, 1977, p. 228.

${ }^{51}$ SILVA, Antonio de Moraes. Diccionario da lingua portugueza. 8. ed. Rio de Janeiro: Empreza Litteraria Fluminense, 1889, v. I, p. 284.

${ }^{52}$ BUENO, Francisco da Silveira. Grande dicionário etimológico-prosódico da língua portuguesa. Saraiva: São Paulo, 1963, v. 1, p. 445 [itálicos do autor].

${ }^{53}$ BUENO, Francisco da Silveira. Grande dicionário etimológico-prosódico da língua portuguesa. Saraiva: São Paulo, 1963, v. 1, p. 445 [itálicos do autor].

${ }^{54}$ TORRINHA, Francisco. Dicionário português-latino. 2. ed. Porto: Domingos Barreira, [s.d.], p. 153 [itálicos do autor].

${ }^{55}$ FREIRE, Laudelino. Grande e novíssimo dicionário da língua portuguesa. 2. ed. Rio de Janeiro: José Olympio, 1954, v. I, p. 894. FIGUEIREDO, Cândido de. Dicionário da língua portuguesa. 24. ed. Lisboa: Bertrand, 1991, v. I, p. 333. BUENO, Francisco da Silveira. Grande dicionário etimológico-prosódico da língua portuguesa. Saraiva: São Paulo, 1963, v. 1, p. 445. TORRINHA, Francisco. Dicionário portuguêslatino. 2. ed. Porto: Domingos Barreira, 1939, p. 152-153.

${ }^{56}$ BUENO, Francisco da Silveira. Grande dicionário etimológico-prosódico da língua portuguesa. Saraiva: São Paulo, 1963, v. 1, p. 445 [itálicos do autor].

${ }^{57}$ HOUAISS, Antonio; VILLAR, Mauro de Salles. Dicionário Houaiss da língua portuguesa. Rio de Janeiro: Objetiva, 2009, p. 226.

${ }^{58}$ SARAIVA, F. R. dos Santos. Novissimo diccionario latino-portuguez: etymologico, prosódico, histórico, geográfico, mythologico, biográfico, etc.. Rio de Janeiro: B. L. Garnier, [s.d.], v. I, p. 125. “Auctoritas, atis, s. ap. f. (de auctor). [...]; $5^{\circ}$ Crédito, crença, fé, confiança nas pessoas e nas coisas; $6^{\circ}$ Vontade, querer, desejo; $7^{\circ}$ Decreto, resolução, determinação com força de lei; sentença, julgamento; $8^{\circ}$ Direito; poder, poderio, jurisdição; [...]".

${ }^{59}$ FREIRE, Laudelino. Grande e novíssimo dicionário da língua portuguesa. 2. ed. Rio de Janeiro: José Olympio, 1954, v. I, p. 894.

${ }^{60}$ SARAIVA, F. R. dos Santos. Novissimo diccionario latino-portuguez: etymologico, prosódico, histórico, geográfico, mythologico, biográfico, etc.. Rio de Janeiro: B. L. Garnier, [s.d.], v. I, p. 124. "Auctor, oris, $s$. ap. $m . f$. (de augere). $1^{\circ} \mathrm{O}$ que produz, gera, faz nascer; [...]; $3^{\circ}$ Auctoridade, caução, fiança, abonador, fiador, garante; [...]; $5^{\circ} \mathrm{O}$ que está investido do poder de fazer uma coisa, de approvar, auctorisar, ratificar; conselheiro, diretor, tutor, testador; [...]; $8^{\circ}$ Procurador, agente, encarregado de; patrono, protector, advogado, defensor, vingador, punidor".

${ }^{61}$ SILVA, Antonio de Moraes. Diccionario da lingua portugueza. 8. ed. Rio de Janeiro: Empreza Litteraria Fluminense, 1889, v. I, p. 284. "(Auctoridade ou Autoridade. Poder. Potestade. Syn) Auctoridade é a superioridade legal, i. é, a estabelecida pela lei da natureza, pela lei divina positiva, pela lei humana, ou pela 
Logo, autorização, substantivo feminino derivado da sufixação do verbo transitivo "autorizar" + "-ção", ${ }^{63}$ denota a "ação de autorizar, de dar poder, permissão, licença, para fazer alguma coisa". ${ }^{64}$

Destaca-se ainda que, na língua portuguesa, a palavra "autor" derivou do arcaico outor, advindo do latim auctore ${ }^{65}$ razão pela qual o verbo "outorgar" advém do latim auctoricare e do frequentativo de auctorare, autorizar. ${ }^{66}$ Consequentemente, outorgar, sendo sinônimo de autorizar, tem o significado de dar poder; permitir; aprovar. ${ }^{67}$

Seguindo esta linha de revelação da etimologia e do significado da palavra "autorização", importa situá-la dentro da classe de palavras a indicar uma mesma ideia.

Na linguagem comum, a palavra "autorização" pertence à classe de palavras que, em maior ou menor grau de proximidade ou exatidão, "exprimem faculdade volitiva" 68 mais precisamente, uma "vontade intersocial". ${ }^{69}$ À ideia de exercício da vontade no âmbito das relações interpessoais a palavra "autorização" pode ser empregada tanto em sentido geral como em sentido específico.

Em sentido geral, a palavra "autorização" indica a ideia de "outorgação de poder". ${ }^{70}$ São indicados a exprimir esta ideia os substantivos: "procura", "procuração",

lei da opinião. Poder é a auctoriedade com força de se fazer respeitar e obedecer. A Potestade nasce do poder legal, que a sustenta, pois não ha potestade sem poder. Os clássicos usam muitas vezes d'esta palavra com a significação generica de poder, forças; mas agora de ordinario só a usamos falando das pessoas que teem poder, divinas, angélicas ou humanas" [itálicos do autor].

${ }^{62}$ FREIRE, Laudelino. Grande e novissimo dicionário da língua portuguesa. 2. ed. Rio de Janeiro: José Olympio, 1954, v. I, p. 894.

${ }^{63}$ HOUAISS, Antonio; VILLAR, Mauro de Salles. Dicionário Houaiss da língua portuguesa. Rio de Janeiro: Objetiva, 2009, p. 226. FREIRE, Laudelino. Grande e novíssimo dicionário da língua portuguesa. 2. ed. Rio de Janeiro: José Olympio, 1954, v. I, p. 894. BUENO, Francisco da Silveira. Grande dicionário etimológico-prosódico da língua portuguesa. Saraiva: São Paulo, 1963, v. 1, p. 445. PRADO E SILVA, Adalberto et. al. Dicionário brasileiro da língua portuguesa. 2. ed. São Paulo: Mirador Internacional, 1977, p. 228.

${ }^{64}$ SILVA, Antonio de Moraes. Diccionario da lingua portugueza. 8. ed. Rio de Janeiro: Empreza Litteraria Fluminense, 1889, v. I, p. 284. Nesse sentido: FIGUEIREDO, Cândido de. Dicionário da língua portuguesa. 24. ed. Lisboa: Bertrand, 1991, v. I, p. 333.

${ }^{65}$ NASCENTES, Antenor. Dicionário etimológico da língua portuguesa. Rio de Janeiro: Francisco Alves, 1955, t. I, p. 54. "Autor - Do lat. auctore. Arc. outor. cfr. outorgar. Se o outor quiser defender en iuizo ... (Leges, pg. 228-A. 1273)" [itálicos do autor].

${ }^{66}$ NASCENTES, Antenor. Dicionário etimológico da língua portuguesa. Rio de Janeiro: Francisco Alves, 1955, t. I, p. 370. CUNHA, Antônio Geraldo da. Dicionário etimológico da língua portuguesa. 4. ed. Rio de Janeiro: Lexikon, 2010, p. 467. HOUAISS, Antonio; VILLAR, Mauro de Salles. Dicionário Houaiss da lingua portuguesa. Rio de Janeiro: Objetiva, 2009, p. 1406.

${ }^{67}$ HOUAISS, Antonio; VILLAR, Mauro de Salles. Dicionário Houaiss da língua portuguesa. Rio de Janeiro: Objetiva, 2009, p. 1406.

${ }^{68}$ SPITZER, Carlos. Dicionário analógico da língua portuguesa: tesouro de vocábulos e frases da língua portuguesa. 6. ed. Porto Alegre: Globo, 1957, p. 191.

${ }^{69}$ SPITZER, Carlos. Dicionário analógico da língua portuguesa: tesouro de vocábulos e frases da língua portuguesa. 6. ed. Porto Alegre: Globo, 1957, p. 241.

${ }^{70}$ SPITZER, Carlos. Dicionário analógico da língua portuguesa: tesouro de vocábulos e frases da língua portuguesa. 6. ed. Porto Alegre: Globo, 1957, § 527, p. 246. 
"legitimação", “aprovação", “consentimento”, "procurador”, "núncio”, "representante”. 71 Neste grupo estão inclusos as expressões e os verbos: "revestir de poder", "dar faculdade", "munir de poderes", "autorizar", “delegar amplos/plenos poderes a”, “dar procuração", “consentir”, "legitimar", “confirmar”, "representar", “aprovar”. 72

Em sentido específico, a palavra "autorização" indica a ideia de: "licença", 73 "consentimento", “concessão", "aprovação", "confirmação". ${ }^{74}$ São indicados a exprimir esta ideia os substantivos: "faculdade", "consentimento", "tolerância", "autorização", "poder", 75 bem como os verbos: "permitir", "autorizar", “conceder", “deferir plenos poderes". ${ }^{76}$

Em outra linha classificatória relativa às palavras a externar igual ideia há a classe de palavras a exprimir uma "faculdade cognoscitiva". ${ }^{77}$ Nela há a subclasse de palavras a exprimir o "resultado do raciocínio", 78 pertencendo a esta subclasse a palavra "assentimento", 79 substantivo masculino decorrente do verbo transitivo indireto "assentir", ${ }^{80}$ que significa "anuir, estar de acordo, aprovar"; 81 "consentir, concordar, aquiescer". ${ }^{82}$ Expressam a ideia de assentimento os substantivos "consentimento",

\footnotetext{
${ }^{71}$ SPITZER, Carlos. Dicionário analógico da língua portuguesa: tesouro de vocábulos e frases da língua portuguesa. 6. ed. Porto Alegre: Globo, 1957, § 527, p. 246.

${ }^{72}$ SPITZER, Carlos. Dicionário analógico da língua portuguesa: tesouro de vocábulos e frases da língua portuguesa. 6. ed. Porto Alegre: Globo, 1957, § 527, p. 246.

${ }^{73}$ SPITZER, Carlos. Dicionário analógico da língua portuguesa: tesouro de vocábulos e frases da língua portuguesa. 6. ed. Porto Alegre: Globo, 1957, § 529, p. 247.

${ }^{74}$ SPITZER, Carlos. Dicionário analógico da língua portuguesa: tesouro de vocábulos e frases da língua portuguesa. 6. ed. Porto Alegre: Globo, 1957, § 531, p. 247.

${ }^{75}$ SPITZER, Carlos. Dicionário analógico da língua portuguesa: tesouro de vocábulos e frases da língua portuguesa. 6. ed. Porto Alegre: Globo, 1957, § 529, p. 247.

${ }^{76}$ SPITZER, Carlos. Dicionário analógico da língua portuguesa: tesouro de vocábulos e frases da língua portuguesa. 6. ed. Porto Alegre: Globo, 1957, § 531, p. 247.

${ }^{77}$ SPITZER, Carlos. Dicionário analógico da língua portuguesa: tesouro de vocábulos e frases da língua portuguesa. 6. ed. Porto Alegre: Globo, 1957, p. 150.

${ }^{78}$ SPITZER, Carlos. Dicionário analógico da língua portuguesa: tesouro de vocábulos e frases da língua portuguesa. 6. ed. Porto Alegre: Globo, 1957, p. 158. AZEVEDO, Francisco Ferreira dos Santos. Dicionário analógico da língua portuguesa: ideias afins/thesaurus. 2. ed. Rio de Janeiro: Lexikon, 2010, p. 199.

79 AZEVEDO, Francisco Ferreira dos Santos. Dicionário analógico da língua portuguesa: ideias afins/thesaurus. 2. ed. Rio de Janeiro: Lexikon, 2010, § 488, p. 204.

${ }^{80}$ SARAIVA, F. R. dos Santos. Novissimo diccionario latino-portuguez: etymologico, prosódico, histórico, geográfico, mythologico, biográfico, etc.. Rio de Janeiro: B. L. Garnier, [s.d.], v. I, p. 114. "Assentio ou Adsentio, is, si, sum, ire, $v$. intrans.. Ser do mesmo parecer, opinião, voto, approvar, apoiar, confirmar".

${ }^{81}$ BUENO, Francisco da Silveira. Grande dicionário etimológico-prosódico da língua portuguesa. Saraiva: São Paulo, 1963, v. 1, p. 387.

${ }^{82}$ HOUAISS, Antonio; VILLAR, Mauro de Salles. Dicionário Houaiss da lingua portuguesa. Rio de Janeiro: Objetiva, 2009, p. 204.
} 
"autorização", "ratificação", "confirmação", "aprovação", "anuência", ${ }^{83}$ assim como os verbos "consentir", "ratificar", “confirmar", "aprovar". 84

Avançando a análise para o interior do mundo do direito, a partir da leitura dos léxicos jurídicos, apresenta a palavra "autorização", em sentido geral, o significado da linguagem comum de permissão ou consentimento manifestado por determinado sujeito a outrem à prática ou abstenção de algum ato, indicando o sentido de outorga de poder. ${ }^{85}$ Apresentam igual significado de "autorização" os termos "anuência", 86 "consentimento", 87

83 AZEVEDO, Francisco Ferreira dos Santos. Dicionário analógico da língua portuguesa: ideias afins/thesaurus. 2. ed. Rio de Janeiro: Lexikon, 2010, § 488, p. 204.

${ }^{84}$ AZEVEDO, Francisco Ferreira dos Santos. Dicionário analógico da língua portuguesa: ideias afins/thesaurus. 2. ed. Rio de Janeiro: Lexikon, 2010, § 488, p. 204.

${ }^{85}$ PLÁCIDO E SILVA, Oscar Josef de. Vocabulário jurídico. Rio de Janeiro: Forense, 1967, v. I, p. 200. “AUTORIZAÇÃO. Em qualquer sentido jurídico, que se lhe dê, autorização significa sempre a permissão ou consentimento dado ou manifestado por certa pessoa, seja física ou jurídica, pública ou privada, para que se pratique ato ou se faça alguma coisa, que não seriam legalmente válidos, sem essa formalidade.

Esse consentimento ou essa permissão, implicando prévia aprovação ao ato que vai ser praticado, seja dada de modo expresso ou de modo tácito, segundo as circunstâncias e a forma de sua manifestação, põe em evidência o poder ou o direito decorrente da autoridade da pessoa ou entidade, a quem cabe autorizar.

Desse modo, a autorização em certos casos, objetiva mesmo o poder recebido para que se exercite o ato ou se realize qualquer negócio.

E, sendo assim, quando se diz que alguém tem autorização para agir, depreende-se claramente que está investido de poderes inequívocos para praticar os atos consentidos ou permitidos (autorizados).

A autorização pode ser para a prática de atos, ou abstenção deles.

A autorização, em certas circunstâncias, possui o mesmo sentido de outorga ou mandato" [itálicos do autor]. NUNES, Pedro dos Reis. Dicionário de tecnologia jurídica. 12. ed. Rio de Janeiro: Freitas Bastos, 1990, p. 116. "AUTORIZAÇÃO - Poder ou permissão judicial, supletiva ou corretiva, administrativa ou particular, outorgada expressamente a alguém, nos casos e pela forma determinada na lei, ou regulamento, para que faça alguma coisa ou pratique certo ato jurídico: autorização do juiz, autorização da prefeitura, autorização do marido, autorização do tutor, etc. Em certos casos pode ser expressa ou tácita. [...]" [itálicos do autor].

${ }^{86}$ PLÁCIDO E SILVA, Oscar Josef de. Vocabulário jurídico. Rio de Janeiro: Forense, 1967, v. I, p. 123. "ANUÊNCIA. Palavra que se origina do latim (annuere), tem, na linguagem jurídica, o sentido de indicar assentimento, aprovação, autorização de uma pessoa para que se pratique ato jurídico, cuja validade depende dessa formalidade.

É usada no sinônimo de consentimento" [itálicos do autor]. NUNES, Pedro dos Reis. Dicionário de tecnologia jurídica. 12. ed. Rio de Janeiro: Freitas Bastos, 1990, p. 77. "ANUÊNCIA - Manifestação da vontade favorável à conclusão de um ato jurídico. Pode ser expressa ou tácita, conforme o ato exija, ou não, consentimento ou aprovação escrita ou verbal. Pedido de - O mesmo que agrément" [itálicos do autor].

${ }^{87}$ PLÁCIDO E SILVA, Oscar Josef de. Vocabulário jurídico. Rio de Janeiro: Forense, 1967, v. I, p. 407. "CONSENTIMENTO. Derivado do verbo latino consentire (ter o mesmo sentir, estar de acordo, concordar), possui, na terminologia jurídica, a acepção de manifestação da vontade, séria e definitiva, em virtude da qual a pessoa, concordando com os desejos de outrem, vincula-se à obrigação ou obrigações, que servem de objeto ao ato jurídico ou ao contrato firmado entre elas.

$[\ldots]$.

Mas, em sentido geral, o consentimento também expressa o significado de aprovação, consequente de estar a pessoa de acordo com o ato que se vai praticar, o qual não surtirá efeitos legais sem a satisfação prévia dessa exigência.

Diz-se, mais particularmente de outorga porque, em verdade, semelhante consentimento não somente revela a condição de estar a pessoa de acordo ou conforme ao ato que se vai praticar: cabendo-lhe autorizar a execução, dando seu consentimento, confere o poder à pessoa, para que o pratique" [itálicos do autor]. NUNES, Pedro dos Reis. Dicionário de tecnologia jurídica. 12. ed. Rio de Janeiro: Freitas Bastos, 1990, p. 229. "CONSENTIMENTO - Manifestação livre de vontade pela qual alguém entra em acordo com uma ou mais pessoas, para a formação de um ato jurídico. Concurso de vontades favoráveis à conclusão de um contrato. Assentimento prévio; aquiescência; consenso. - mútuo - Acordo das vontades de ambas as partes, na realização de um ato jurídico. Consentimento diz-se: 
os quais são indicados como sinônimo de assentimento ${ }^{88}$ e de aprovação. ${ }^{89}$ Igualmente são tratados como sinônimo de autorização os termos "outorga", 90 "permissão"91 e "licença". ${ }^{92}$

a) expresso, quando é efetuado verbalmente, ou por escrito, ou por outros sinais inequívocos que substituam as palavras;

b) tácito ('tacita assensio'), quando resulta de ato ou fato que revela, da parte do agente, a intenção de anuir ou assentir" [itálicos do autor].

${ }^{88}$ PLÁCIDO E SILVA, Oscar Josef de. Vocabulário jurídico. Rio de Janeiro: Forense, 1967, v. I, p. 169. "ASSENTIMENTO. O mesmo que consentimento ou anuência" [itálicos do autor]. NUNES, Pedro dos Reis. Dicionário de tecnologia jurídica. 12. ed. Rio de Janeiro: Freitas Bastos, 1990, p. 96. "ASSENTIMENTO — Consentimento, aquiescência, aprovação a um ato".

${ }^{89}$ PLÁCIDO E SILVA, Oscar Josef de. Vocabulário jurídico. Rio de Janeiro: Forense, 1967, v. I, p. 140. "APROVAÇÃO. Palavra originada do latim approbatio, de approbare (aprovar), tem o sentido genérico de consentimento ou anuência à prática de um ato escrito.

Mas, também significa o reconhecimento que é feito por uma pessoa em relação ao ato anteriormente praticado, a fim de que se lhe dê existência jurídica ou se lhe confirme autenticidade.

Neste caso, numa acepção eminentemente forense, tem o mesmo significado de homologação, ratificação ou confirmação por auto judicial, do ato jurídico ou contrato anteriormente feito" [itálicos do autor]. NUNES, Pedro dos Reis. Dicionário de tecnologia jurídica. 12. ed. Rio de Janeiro: Freitas Bastos, 1990, p. 84. "APROVAÇÃO. 1 - Autenticação, por notário público, de ato escrito em que a vontade de outrem se manifesta: aprovação de testamento. 2 - Consentimento de alguém, necessário à existência e validade de certo ato, ou contrato: aprovação de contas. 3 - Beneplácito que é dado pela autoridade superior ao ato praticado por seu subalterno, ou qualquer outra pessoa a ela subordinada" [itálicos do autor].

${ }^{90}$ PLÁCIDO E SILVA, Oscar Josef de. Vocabulário jurídico. Rio de Janeiro: Forense, 1967, v. III, p. 1104. "OUTORGA. Derivado de outorgar (dar consentimento), do latim popular auctorisare (autorizar), é tido na significação jurídica como o consentimento, a autorização, a concessão ou o poder.

No sentido do Direito Privado, entende-se o ato pelo qual se autoriza, se consente ou se dá poder para que se execute $\mathrm{o}$ ato ou se faça qualquer coisa, que não possa ser praticada por outrem sem esse consentimento ou essa autorização.

Neste conceito, outorga exprime, em certos casos os poderes conferidos em um mandato e, até, o próprio mandato: tem outorga, isto é, tem poderes ou está investido em mandato.

Na significação do Direito Público é a concessão: a outorga da Carta Constitucional.

$\mathrm{Na}$ terminologia técnica, quem dá poderes ou consente, diz-se outorgante. Quem recebe os poderes ou é autorizado, diz-se outorgado. Na terminologia do mandato, outorgante corresponde ao mandante, e outorgado ao mandatário.

A outorga pode ser conferida em escrito à parte, ou no próprio ato, que deve ser autorizado ou consentido" [itálicos do autor]. NUNES, Pedro dos Reis. Dicionário de tecnologia jurídica. 12. ed. Rio de Janeiro: Freitas Bastos, 1990, p. 624. "OUTORGA - Consentimento, permissão, concessão, licença, aprovação".

${ }^{91}$ PLÁCIDO E SILVA, Oscar Josef de. Vocabulário jurídico. Rio de Janeiro: Forense, 1967, v. III, p. 1151. "PERMISSÃO. Derivado do latim permissio, do verbo permittire (permitir, consentir, autorizar), na terminologia jurídica entende-se o consentimento, a autorização ou a licença, para que faça alguma coisa, que não é de nosso direito, ou para cuja execução ou prática se exija o consentimento ou a autorização do poder público, como formalidade ou como exigência preliminar.

$[\ldots]$

No sentido do Direito Privado, a permissão exprime sempre o consentimento ou a autorização dada, por quem possa ou tenha autoridade para consentir, à pessoa para que pratique o ato ou execute alguma coisa, que não poderia, validamente, executar ou fazer sem este consentimento" [itálicos do autor].

NUNES, Pedro dos Reis. Dicionário de tecnologia jurídica. 12. ed. Rio de Janeiro: Freitas Bastos, 1990, p. 650. "PERMISSÃO - Autorização, consentimento expresso para fazer alguma coisa ou praticar certo ato: permissão de exercício, de casar, de ausentar-se do país, etc." [itálico do autor].

${ }_{92}$ PLÁCIDO E SILVA, Oscar Josef de. Vocabulário jurídico. Rio de Janeiro: Forense, 1967, v. III, p. 943944. "LICENÇA. Derivado do latim licentia, de licet (ser permitido, ser possível), em sentido geral quer exprimir a permissão ou a autorização dada a alguém para que possa fazer ou deixar de fazer alguma coisa. Mas, essa autorização, em que se funda a licença, importa sempre numa concessão ou ato emanado de pessoa, a quem se dê autoridade ou poder para consentir ou autorizar a prática dos atos ou das atividades, que lhe servem de objeto. É, por isso, autorização superior que vem tornar lícito ou válido o que não se poderia fazer sem o preenchimento da formalidade, de que resulta a licença" [itálicos do autor]. 
Essas palavras, a entrecruzarem-se em seus significados tanto na linguagem comum como na linguagem jurídica, foram empregadas pelo legislador no Código Civil como elementos do suporte fático de diversas normas. ${ }^{93}$ Nesse sentido, várias dúvidas e dificuldades à compreensão exsurgem se, por exemplo, efetuada a leitura dos arts. 176, ${ }^{94}$ $220,{ }^{95} 1.649^{96}$ e $1.650^{97}$ do Código Civil.

Das precitadas regras jurídicas ressaltam, como elementos de seus suportes fáticos, os seguintes termos: "autorização", "validado", "posteriormente", anuência", “consentimento", "assentimento", “outorga”, “suprimento". Os termos destacados suscitam várias indagações: (i) anuir é sinônimo de autorizar?; (ii) a autorização é requisito apenas ao plano da validade dos atos jurídicos lato sensu?; (iii) quando falta autorização de um dos cônjuges para a conclusão de negócio jurídico, a aprovação é sinônimo de autorização posteriormente prestada ou são palavras dotadas de significados técnicos e jurídicos distintos?; (iv) a outorga e o consentimento são figuras jurídicas distintas e, por isso, espécies de autorização, ou todas, em verdade, apresentam significados distintos?; (v) serão sinônimos os termos "assentimento", "consentimento", "autorização" e "anuência", dado o tratamento analógico dispensado no Código Civil? ${ }^{98}$

Essa imprecisão da linguagem, já existente no Código Civil ab-rogado, demonstra que a Comissão Redatora do Código Civil em vigor não atendeu, como proclamou, ao princípio da operabilidade ${ }^{99} \mathrm{em}$ sua integralidade. As normas deveriam ter sido redigidas de modo a afastar "sinonímias", 100 dando "unidade expressional" 101 e "rigor técnico-

\footnotetext{
${ }^{93}$ No Código Civil em vigor a palavra "autorização" figura por 76 vezes, como elemento do suporte fático de normas jurídicas.

${ }^{94}$ Art. 176 do Código Civil: "Quando a anulabilidade do ato resultar de falta de autorização de terceiro, será validado se este se der posteriormente".

${ }^{95}$ Art. 220 do Código Civil: "A anuência ou a autorização de outrem, necessária à validade de um ato, provar-se-á do mesmo modo que este, e constará, sempre que se possa, do próprio instrumento".

${ }_{96}$ Art. 1.649 do Código Civil: "A falta de autorização, não suprida pelo juiz, quando necessária (art. 1.647), tornará anulável o ato praticado, podendo o outro cônjuge pleitear-lhe a anulação, até dois anos depois de terminada a sociedade conjugal. Parágrafo único. A aprovação torna válido o ato, desde que feita por instrumento público, ou particular, autenticado".

97 Art. 1.650 do Código Civil: "A decretação de invalidade dos atos praticados sem outorga, sem consentimento, ou sem suprimento do juiz, só poderá ser demandada pelo cônjuge a quem cabia concedê-la, ou por seus herdeiros".

${ }^{98}$ Outro não foi o questionamento do professor Alcides Tomasetti Júnior, ao comentar o art. $3^{\text {o }}$ da Lei 8.245/91, que impõe a vênia conjugal como pressuposto para que o contrato de locação venha a ser concluído com prazo igual ou superior a dez anos: "Serão sinônimos os termos 'consentimento', 'autorização' e 'vênia', dada a analogia entre os fins tutelados pelos referidos artigos de lei? Em resumo: 'vênia conjugal' é o mesmo que 'consentimento da mulher' e 'autorização do marido'?” (TOMASETTI JR., Alcides et. al. Comentários à lei de locações de imóveis urbanos: Lei n. 8.245, de 18 de outubro de 1991. Coord. Juarez de Oliveira. São Paulo: Saraiva, 1992, p. 47).

${ }^{99}$ REALE, Miguel. História do novo Código Civil. São Paulo: Revista dos Tribunais, 2005, p. 40.

${ }^{100}$ REALE, Miguel. História do novo Código Civil. São Paulo: Revista dos Tribunais, 2005, p. 40.

${ }^{101}$ REALE, Miguel. História do novo Código Civil. São Paulo: Revista dos Tribunais, 2005, p. 84.
} 
conceitual"102 para "facilitar a interpretação e aplicação pelo operador do Direito", ${ }^{103}$ mas, em grande parte, não o foram. Esta imprecisão é reforçada por inexistir uma detalhada exposição de motivos do Código Civil, a explicitar se certa palavra foi empregada com significado específico pelo legislador. ${ }^{104}$

Por se estar perante uma área dotada de imprecisão linguística, ${ }^{105}$ a resposta a essas questões "seria já de si muito importante se apenas fosse relativa ao aperfeiçoamento puramente terminológico da dogmática jurídica", ${ }^{106}$ porquanto a falta de precisão da linguagem técnico-jurídica tem como reflexo a insegurança à aplicação do direito. ${ }^{107}$

Por esta ausência de definição, existente desde o Código Civil ab-rogado, caberia à doutrina privatista a revelação e a fixação do sentido da palavra "autorização" no sistema jurídico interno. Contudo, ela apenas tangenciou o provável significado jurídico de autorização e sua eficácia jurídica. Restringiu-se a apenas apresentar, em poucas linhas, a autorização em sentido amplo ${ }^{108}$ como figura jurídica distinta da procura, ${ }^{109}$ da

${ }^{102}$ REALE, Miguel. História do novo Código Civil. São Paulo: Revista dos Tribunais, 2005, p. 84.

${ }^{103}$ REALE, Miguel. História do novo Código Civil. São Paulo: Revista dos Tribunais, 2005, p. 40.

104 Para comprovar a aplicação parcial do princípio da operabilidade, basta observar que, visando dar precisão e distinguir figuras jurídicas, o legislador empregou nos arts. 172 a 175 do Código Civil o termo "confirmação" ao contrário do termo "ratificação", como constava nos arts. 148 a 151 do Código Civil abrogado. Sobre esta alteração: REALE, Miguel. História do novo Código Civil. São Paulo: Revista dos Tribunais, 2005, p. 84. MOREIRA ALVES, José Carlos. A parte geral do projeto de Código Civil brasileiro (subsídios históricos para o novo Código Civil brasileiro). 2. ed. São Paulo: Saraiva, 2003, p. 94 e 126.

${ }^{105}$ Essa imprecisão linguística quanto ao tema da autorização não é exclusividade do sistema jurídico brasileiro. O problema encontra-se nos sistemas jurídicos italiano, francês, espanhol e português, conforme destacam, para cada um dos sistemas, respectivamente: AURICCHIO, Alberto. Autorizzazione (dir. priv.). Enciclopedia del diritto. Milano: Giuffrè, 1959, v. IV, p. 503. THULLIER, Béatrice. L'autorisation: étude de droit privé. Paris: LGDJ, 1996, 8-13, p. 6-11. GONZÁLEZ, Blas Pérez. ALGUER, José. GETE-ALONSO, Maria del Carmen. Notas. In: ENNECCERUS, Ludwig; KIPP, Theodor; WOLF, Martin. Tratado de derecho civil. Trad. Blas Pérez González y José Alguer. 3. ed. Barcelona: Bosch, 1981, t. I, v. II — segunda parte, $\S$ 204, p. 791-795. VASCONCELOS, Pedro Leitão Pais de. A autorização. Coimbra: Coimbra, 2012, p. 7. Durante a vigência do Código Civil português ab-rogado: PESSOA JORGE, Fenando de Sandy Lopes. $O$ mandato sem representação. Coimbra: Almedina, 2001, p. 388.

106 TOMASETTI JR., Alcides et. al. Comentários à lei de locações de imóveis urbanos: Lei n. 8.245, de 18 de outubro de 1991. Coord. Juarez de Oliveira. São Paulo: Saraiva, 1992, p. 47.

${ }^{107}$ Aqui volta à memória a seguinte lição de Pontes de Miranda: "Nessa precisão dos termos empregados assenta grande parte do aperfeiçoamento da doutrina. Sem ela, os juízes faltam à missão de realização do direito objetivo e de pacificação entre os homens: por falta de conhecimentos exatos, erram; errando, inserem nos repositórios de arestos, que hão de ser consultados, conceitos e proposições que avolumam a confusão dos não-sabedores e dificultam toda a obra de corrigenda e de ciência do direito" (PONTES DE MIRANDA, Francisco Cavalcanti. Tratado de direito privado. 3. ed. São Paulo: Revista dos Tribunais, 1984, t. XL, § 4.462, 1, p. 315).

${ }^{108}$ PONTES DE MIRANDA, Francisco Cavalcanti. Tratado de direito privado. 4. ed. São Paulo: Revista dos Tribunais, 1983, t. III, $\S 344,1$, p. 400. PONTES DE MIRANDA, Francisco Cavalcanti. Tratado de direito privado. 3. ed. São Paulo: Revista dos Tribunais, 1984, t. XLII, § 4.633, 1, p. 215. TOMASETTI JR., Alcides et. al. Comentários à lei de locações de imóveis urbanos: Lei n. 8.245, de 18 de outubro de 1991. Coord. Juarez de Oliveira. São Paulo: Saraiva, 1992, p. 47-48.

${ }^{109}$ PONTES DE MIRANDA, Francisco Cavalcanti. Tratado de direito privado. 4. ed. São Paulo: Revista dos Tribunais, 1983, t. III, $\S 278,3$, p. 142. 
representação, ${ }^{110}$ do mandato, ${ }^{111}$ do consentimento ${ }^{112}$ e da autorização judicial. ${ }^{113}$

Perante este quadro, para revelar e construir o significado da autorização no âmbito do direito privado, e tendo como fonte legal o Código Civil, não se pode partir do significado existente em outro ramo do direito, como na teoria geral do direito ${ }^{114}$ ou no direito administrativo. ${ }^{115}$ Igualmente, é importante saber discernir, ao se analisar determinada norma do Código Civil, quando a palavra "autorização" está empregada: (a) no sentido da linguagem comum; ${ }^{116}$ (b) para compor regra jurídica outorgativa ou permissiva; ${ }^{117}$ (c) para expressar um significado específico que não o de direito privado,

${ }^{110}$ ESPINOLA, Eduardo. Parte geral: dos factos juridicos. Manual do Código Civil brasileiro. Org. Paulo de Lacerda. Rio de Janeiro: Jacintho Ribeiro dos Santos, 1923, v. III, parte primeira, p. 27-28. CARVALHO DE MENDONÇA, José Xavier. Tratado de direito commercial brasileiro. 2. ed. rev. por Achilles Bevilaqua e Roberto Carvalho de Mendonça. Rio de Janeiro: Freitas Bastos, 1934, v. VI, parte I, § 219, p. 200-201. MAIA JÚNIOR, Mairan Gonçalves. A representação no negócio jurídico. 2. ed. São Paulo: Revista dos Tribunais, 2004, p. 56-57. LOTUFO, Renan. Questões relativas a mandato, representação e procuração. São Paulo: Saraiva, 2001, p. 142-143. LOTUFO, Renan. Código Civil comentado: parte geral. 3. ed. São Paulo: Saraiva, 2016, v. 1, p. 390-392.

${ }^{111}$ CARVALHO DE MENDONÇA, José Xavier. Tratado de direito commercial brasileiro. 2. ed. rev. por Achilles Bevilaqua e Roberto Carvalho de Mendonça. Rio de Janeiro: Freitas Bastos, 1934, v. VI, parte I, § 219, p. 200-201. FERREIRA, Waldemar. Tratado de direito comercial. São Paulo: Saraiva, 1960, v. 2, § 234, p. 121. LOTUFO, Renan. Questões relativas a mandato, representação e procuração. São Paulo: Saraiva, 2001, p. 123-124.

${ }^{112}$ CARVALHO SANTOS, João Manuel de. Código Civil brasileiro interpretado. 7. ed. Rio de Janeiro: Freitas Bastos, 1958, v. III, p. 134-135.

${ }^{113}$ CARVALHO SANTOS, João Manuel de. Código Civil brasileiro interpretado. 7. ed. Rio de Janeiro: Freitas Bastos, 1958, v. III, p. 136.

114 TELLES JR., Goffredo da Silva. Autoridade - Autorização - Autorizar (Teoria geral do direito). Enciclopédia Saraiva do Direito. Coord. Rubens Limongi França. São Paulo: Saraiva, 1978, v. 9, p. 326-347. TELLES JR., Goffredo da Silva. Autorizamento. Enciclopédia Saraiva do Direito. Coord. Rubens Limongi França. São Paulo: Saraiva, 1978, v. 9, p. 376-377. TELLES JR., Goffredo da Silva. Autorizante (Imperativo autorizante: definição de Norma Jurídica). Enciclopédia Saraiva do Direito. Coord. Rubens Limongi França. São Paulo: Saraiva, 1978, v. 9, p. 377-392. KELSEN, Hans. Teoria geral das normas. Trad. José Florentino Duarte. Porto Alegre: Sergio Antonio Fabris, 1986, p. 129.

${ }^{115}$ Sobre o conceito de autorização no direito administrativo e sua distinção das demais espécies de ato administrativo: POMPEU, Cid Tomanik. Autorização administrativa. 3. ed. São Paulo: Revista dos Tribunais, 2009. MELLO, Celso Antônio Bandeira de. Curso de direito administrativo. 30. ed. São Paulo: Malheiros, 2013, p. 442-452. JUSTEN FILHO, Marçal. Curso de direito administrativo. 9. ed. São Paulo: Revista dos Tribunais, 2013, p. 424-431. COMPARATO, Fábio Konder. As autorizações de funcionamento de instituições financeiras. Direito público: estudos e pareceres. São Paulo: Saraiva, 1996, p. 240-252. GASPARRI, Pietro. Autorizzazione (dir. amm.). Enciclopedia del diritto. Milano: Giuffrè, 1959, v. IV, p. 509-516. FORTI, Ugo. Autorizzazione (diritto amministrativo). Novissimo digesto italiano. Torino: UTET, 1958 , v. $1 / 2$, p. $1580-1582$.

${ }^{116}$ E.g., art. 559 do Código Civil: "A revogação por qualquer desses motivos deverá ser pleiteada dentro de um ano, a contar de quando chegue ao conhecimento do doador o fato que a autorizar, e de ter sido o donatária o seu autor".

${ }^{117}$ E.g., art. 111. (O silêncio importa anuência, quando as circunstâncias ou os usos o autorizarem, e não for necessária a declaração de vontade expressa). Art. 143. (O erro de cálculo apenas autoriza a retificação da declaração de vontade). Art. 503. (Nas coisas vendidas conjuntamente, o defeito oculto de uma não autoriza a rejeição de todas). Art. 907. (É nulo o título ao portador emitido sem autorização de lei especial). Art. 1.208. (Não induzem posse os atos de mera permissão ou tolerância assim como não autorizam a sua aquisição os atos violentos, ou clandestinos, senão depois de cessar a violência ou a clandestinidade). Art. 1.379. (O exercício incontestado e contínuo de uma servidão aparente, por dez anos, nos termos do art. 1.242, autoriza o interessado a registrá-la em seu nome no Registro de Imóveis, valendo-lhe como título a sentença que 
por exemplo, de direito administrativo: (c.1) quanto ao início e fim da existência legal das pessoas jurídicas de direito privado, ${ }^{118}$ (c.2) no contrato de transporte, ${ }^{119}$ (c.3) no contrato de seguro, ${ }^{120}$ (c.4) quanto ao funcionamento, no Brasil, de sociedades nacionais e estrangeiras. ${ }^{121}$ Importa também relembrar que, perante as normas do Código Civil, se

julgar consumado a usucapião). Art. 1.962. (Além das causas mencionadas no art. 1.814, autorizam a deserdação dos descendentes por seus ascendentes: I - ofensa física; II - injúria grave; III - relações ilícitas com a madrasta ou com o padrasto; IV - desamparo do ascendente em alienação mental ou grave enfermidade). Art. 1.963. (Além das causas enumeradas no art. 1.814, autorizam a deserdação dos ascendentes pelos descendentes: I - ofensa física; II - injúria grave; III - relações ilícitas com a mulher ou companheira do filho ou a do neto, ou com o marido ou companheiro da filha ou o da neta; IV - desamparo do filho ou neto com deficiência mental ou grave enfermidade).

${ }^{118}$ E.g., art. 45. (Começa a existência legal das pessoas jurídicas de direito privado com a inscrição do ato constitutivo no respectivo registro, precedida, quando necessário, de autorização ou aprovação do Poder Executivo, averbando-se no registro todas as alterações por que passar o ato constitutivo). Art. 51. (Nos casos de dissolução da pessoa jurídica ou cassada a autorização para seu funcionamento, ela subsistirá para os fins de liquidação, até que esta se conclua).

${ }^{119}$ E.g., art. 731 (O transporte exercido em virtude de autorização, permissão ou concessão, rege-se pelas normas regulamentares e pelo que for estabelecido naqueles atos, sem prejuízo do disposto neste Código).

${ }^{120}$ E.g., art. 757 (Pelo contrato de seguro, o segurador se obriga, mediante o pagamento do prêmio, a garantir interesse legítimo do segurado, relativo a pessoa ou a coisa, contra riscos predeterminados. Parágrafo único. Somente pode ser parte, no contrato de seguro, como segurador, entidade para tal fim legalmente autorizada).

${ }^{121}$ E.g., art. 1.123 (A sociedade que dependa de autorização do Poder Executivo para funcionar reger-se-á por este título, sem prejuízo do disposto em lei especial. Parágrafo único. A competência para a autorização será sempre do Poder Executivo federal); art. 1.124 (Na falta de prazo estipulado em lei ou em ato do poder público, será considerada caduca a autorização se a sociedade não entrar em funcionamento nos doze meses seguintes à respectiva publicação); art. 1.125 (Ao Poder Executivo é facultado, a qualquer tempo, cassar a autorização concedida a sociedade nacional ou estrangeira que infringir disposição de ordem pública ou praticar atos contrários aos fins declarados no seu estatuto); Art. 1.128 (O requerimento de autorização de sociedade nacional deve ser acompanhado de cópia do contrato, assinada por todos os sócios, ou, tratando-se de sociedade anônima, de cópia, autenticada pelos fundadores, dos documentos exigidos pela lei especial); Art. 1.130 (Ao Poder Executivo é facultado recusar a autorização, se a sociedade não atender às condições econômicas, financeiras ou jurídicas especificadas em lei); Art. 1.131 (Expedido o decreto de autorização, cumprirá à sociedade publicar os atos referidos nos arts. 1.128 e 1.129, em trinta dias, no órgão oficial da União, cujo exemplar representará prova para inscrição, no registro próprio, dos atos constitutivos da sociedade. [...] $\S 2^{\circ}$ Obtida a autorização e constituída a sociedade, proceder-se-á à inscrição dos seus atos constitutivos); Art. 1.133 (Dependem de aprovação as modificações do contrato ou do estatuto de sociedade sujeita a autorização do Poder Executivo, salvo se decorrerem de aumento do capital social, em virtude de utilização de reservas ou reavaliação do ativo); art. 1.134 (A sociedade estrangeira, qualquer que seja o seu objeto, não pode, sem autorização do Poder Executivo, funcionar no País, ainda que por estabelecimentos subordinados, podendo, todavia, ressalvados os casos expressos em lei, ser acionista de sociedade anônima brasileira. $\S 1^{\circ}$ Ao requerimento de autorização devem juntar-se: I - prova de se achar a sociedade constituída conforme a lei de seu país; II - inteiro teor do contrato ou do estatuto; III - relação dos membros de todos os órgãos da administração da sociedade, com nome, nacionalidade, profissão, domicílio e, salvo quanto a ações ao portador, o valor da participação de cada um no capital da sociedade; IV - cópia do ato que autorizou o funcionamento no Brasil e fixou o capital destinado às operações no território nacional; V - prova de nomeação do representante no Brasil, com poderes expressos para aceitar as condições exigidas para a autorização; VI - último balanço); art. 1.135 (É facultado ao Poder Executivo, para conceder a autorização, estabelecer condições convenientes à defesa dos interesses nacionais. Parágrafo único. Aceitas as condições, expedirá o Poder Executivo decreto de autorização, do qual constará o montante de capital destinado às operações no País, cabendo à sociedade promover a publicação dos atos referidos no art. $1.131 \mathrm{e}$ no $\S 1^{\circ}$ do art. 1.134); art. 1.136 (A sociedade autorizada não pode iniciar sua atividade antes de inscrita no registro próprio do lugar em que se deva estabelecer. $\S 2^{\circ}$ Arquivados esses documentos, a inscrição será feita por termo em livro especial para as sociedades estrangeiras, com número de ordem contínuo para todas as sociedades inscritas; no termo constarão: [...]; III - data e número do decreto de autorização); Art. 1.140 (A sociedade estrangeira deve, sob pena de lhe ser cassada a autorização, reproduzir no órgão oficial da União, e do Estado, se for o caso, as publicações que, segundo a sua lei nacional, seja obrigada a fazer relativamente 
deve observar que o legislador, buscando sentido técnico-jurídico, pode ter empregado palavra análoga quanto ao significado na linguagem comum, mas que não coincide com o sentido do direito privado - por exemplo, autorização no lugar de aprovação ou de permissão. Como anteriormente destacado, há que buscar o sentido literal da palavra no ramo do direito em que está inserida. ${ }^{122}$

Por se constatar a vagueza da palavra autorização no direito privado brasileiro - a ponto de se duvidar que efetivamente apresenta significado jurídico neste ramo, e por se ter plena consciência de que o "mister doutrinário não é apenas o de explicitar o direito positivado, esclarecendo significado dos textos, mas, justamente, o de construir soluções jurídicas úteis à prática, possibilitando resolver os problemas da humana convivência"123 —, foi elaborado o seguinte problema para a construção da presente tese: O que é a autorização no direito privado?

Para a resolução deste problema apresentamos quatro hipóteses. A primeira é que, assente em específicos suportes fáticos legais, insertos no Código Civil, é possível atribuir um significado normativo à palavra "autorização" no campo do direito privado. A segunda hipótese é ser a autorização espécie de assentimento prévio pertencente à teoria geral do assentimento, que, embora não esteja expressamente identificada e sistematizada, também se vê presente no Código Civil. A terceira hipótese é a de apresentar a autorização duas espécies: (i) a integrativa e (ii) a autorização para dispor, pelo consectário de ser espécie de

ao balanço patrimonial e ao de resultado econômico, bem como aos atos de sua administração. Parágrafo único. Sob pena, também, de lhe ser cassada a autorização, a sociedade estrangeira deverá publicar o balanço patrimonial e o de resultado econômico das sucursais, filiais ou agências existentes no País); art. 1.141 (Mediante autorização do Poder Executivo, a sociedade estrangeira admitida a funcionar no País pode nacionalizar-se, transferindo sua sede para o Brasil. [...]. $\S 3^{\circ}$ Aceitas as condições pelo representante, proceder-se-á, após a expedição do decreto de autorização, à inscrição da sociedade e publicação do respectivo termo).

122 PONTES DE MIRANDA, Francisco Cavalcanti. Tratado de direito privado. 4. ed. São Paulo: Revista dos Tribunais, 1983, t. I, p. XIII-XIV. “Os trabalhos preparatórios são, portanto, elemento de valor mínimo. O que foi publicado é a letra da lei, com suas palavras e frases. Tem-se de interpretar, primeiro, gramaticalmente, mas já aí as palavras podem revelar sentido que não coincide com o do dicionário vulgar (pode lá estar rescisão, e tratar-se de resolução; pode lá estar condição, e não ser de condicio que se há de cogitar; pode falar-se de erro, e só se dever entender erro de fato, e não o de direito). O sentido literal é o sentido literal da ciência do direito, tendo-se em vista que o próprio redator da lei, ao redigi-la, exercia função da dimensão política, e não da dimensão jurídica, pode não ser jurista ou ser mau jurista, ou falso jurista, o que é pior. Demais, estava ele a redigir regra jurídica, ou regras jurídicas, que se vão embutir no sistema jurídico e tal inserção não é sem consequências para o conteúdo das regras jurídicas, nem sem consequências para o conteúdo das regras jurídicas, nem sem consequências para o sistema jurídico. Jurisprudência contra lei é jurisprudência contra esse resultado. Por isso, regra jurídica não escrita pode dilatar ou diminuir o conteúdo da regra jurídica nova. Daí, quando se lê a lei, em verdade se ter na mente o sistema jurídico, em que ela entra, e se ler na história, no texto e na exposição sistemática. Os erros de expressão da lei são corrigidos facilmente porque o texto fica entre esses dois componentes do material para a fixação do verdadeiro sentido" [itálicos do autor].

${ }^{123}$ MARTINS-COSTA, Judith. Autoridade e utilidade da doutrina: a construção dos modelos doutrinários. Modelos de direito privado. Org. Judith Martins-Costa. São Paulo: Marcial Pons, 2014, p. 14. 
assentimento prévio e em razão de determinados suportes fáticos legais. Como quarta hipótese sustenta-se que a eficácia da autorização é atribuir legitimidade ao autorizado para concluir negócio jurídico válido ou eficaz, a depender do suporte fático legal que a exige.

Identificados o problema e as hipóteses, o objetivo principal desta tese é revelar a autorização como figura jurídica autônoma na teoria geral do direito privado, atribuindolhe significado preciso dentro do quadro normativo em que está estabelecida, e apresentar suas espécies, suas respectivas características e seus efeitos jurídicos.

Considerando o problema formulado, as hipóteses propostas e o objetivo visado, pretende-se criar um modelo doutrinário capaz de fornecer não só "uma ordenada atividade de integração hermenêutica", 124 mas também conferir "significação" 125 e "inteligibilidade" 126 às normas jurídicas que apresentam, como elemento de seu suporte fático, a palavra "autorização". É fator a ressaltar, para a relevância da presente tese, a circunstância de apresentar, ante a ausência de monografias elaboradas pela doutrina jurídica brasileira a tratar sobre o tema, uma contribuição original à ciência jurídica brasileira.

A base normativa para a construção do presente trabalho foi o sistema jurídico brasileiro, em especial o Código Civil. Contudo, dada a ausência de monografias específicas sobre o tema na literatura jurídica nacional, mostrou-se essencial ter por arrimo a doutrina estrangeira, e pelo desenvolvimento doutrinário que apresenta sobre a autorização. Em especial foram importantíssimos os modelos dogmáticos cunhados pelas doutrinas alemã e italiana, assim como os modelos português, espanhol e francês. Acentuase que o uso da doutrina estrangeira não teve por escopo desenvolver capítulo sobre direito comparado, mas servir à reflexão e à construção, à luz do sistema jurídico interno, dos argumentos a compor a presente tese.

Visando abordar a autorização nos limites do sistema jurídico estruturante do direito privado brasileiro, construímos a tese em dois parágrafos, com seus respectivos subparágrafos.

No parágrafo primeiro $\left(\S 1^{\circ}\right)$, a partir dos suportes fáticos dos arts. 176 e 220 do Código Civil, e dos conceitos de figurante, parte e terceiro, identifica-se a autorização

\footnotetext{
${ }^{124}$ MARTINS-COSTA, Judith. Autoridade e utilidade da doutrina: a construção dos modelos doutrinários. Modelos de direito privado. Org. Judith Martins-Costa. São Paulo: Marcial Pons, 2014, p. 27.

${ }^{125}$ MARTINS-COSTA, Judith. Autoridade e utilidade da doutrina: a construção dos modelos doutrinários. Modelos de direito privado. Org. Judith Martins-Costa. São Paulo: Marcial Pons, 2014, p. 31.

${ }^{126}$ MARTINS-COSTA, Judith. Autoridade e utilidade da doutrina: a construção dos modelos doutrinários. Modelos de direito privado. Org. Judith Martins-Costa. São Paulo: Marcial Pons, 2014, p. 31.
} 
como a declaração de vontade de sujeito de direito não figurante na parte de um negócio jurídico (subparágrafo 1). É igualmente evidenciado ter a autorização a eficácia de ser elemento complementar do suporte fático do negócio jurídico concluído, para que possa ser válido ou eficaz (subparágrafo 2). Com suporte nesses elementos caracterizadores, mostra-se ser a autorização espécie de assentimento prévio, pertencente à teoria geral do assentimento do direito privado, estando esta teoria implicitamente reconhecida no Código Civil. Comprova-se ser a autorização espécie de assentimento, por ser declaração de vontade de terceiro, imposta a determinados suportes fáticos para proteção de interesses jurídicos do autorizado (assentimento vigilante) ou do autorizante (assentimento autointeressado). Nesse sentido, delimita-se a figura geral do assentimento, apresentam-se suas espécies e organizam-se suas subespécies dispersas no Código Civil, permitindo-se indicar a existência da autorização integrativa e da autorização para dispor (subparágrafo 3). Por fim, apresenta-se uma síntese das dogmáticas alemã e italiana que serviram de suporte à revelação das espécies de autorização no Código Civil.

No parágrafo segundo $\left(\S 2^{\circ}\right)$, preliminarmente, analisam-se os temas relativos ao exercício jurídico e à legitimidade, porquanto, a depender da espécie de autorização e do suporte fático em que é elemento complementar, servirá ao exercício direto ou indireto de posição jurídica do autorizado - e, por conseguinte, gerando-lhe legitimidade à conclusão válida ou eficaz de negócio jurídico (subparágrafo 1). Analisa-se a seguir cada uma das espécies de autorização. Aborda-se a autorização integrativa como figura jurídica autônoma a conferir ao autorizado faculdade jurídica, sendo classificada como negócio jurídico unilateral quanto à sua existência, validade e eficácia, assim como à sua extinção. Apresenta-se igualmente a sua distinção quanto à figura jurídica da permissão (subparágrafo 2). À análise da autorização para dispor, preliminarmente, apresentam-se os suportes fáticos legais relativos aos contratos estimatório e de comissão para venda como fundamento legal passível de revelar, no Código Civil, a figura da autorização para dispor no sistema jurídico interno. Desde esta preliminar, analisa-se a autorização para dispor como figura jurídica autônoma cuja eficácia é atribuir ao autorizado o poder de dispor, em nome próprio, direito do autorizante, sendo também classificada e analisada como negócio jurídico unilateral quanto à sua existência, validade e eficácia, assim como à sua extinção. Ao final, apresenta-se a inadmissibilidade, no sistema jurídico interno, da autorização para cobrança, da autorização para adquirir e da autorização para contrair obrigação (subparágrafo 3). 
Por fim estarão expostas as conclusões relativas ao problema formulado e decorrentes das hipóteses investigadas. 


\section{CONCLUSÃO}

Conquanto as conclusões tenham sido apresentadas, paulatinamente, durante o desenvolvimento da presente tese, estas, na sequência, se encontram sistematizadas de forma articulada.

1) Pela leitura dos arts. 176 e 220 do Código Civil, depreende-se que, para determinados negócios jurídicos serem válidos ou eficazes, deve também existir a declaração de vontade prestada por terceiro - ou seja, por quem não é figurante na parte do negócio jurídico.

2) Essa declaração de vontade gera negócio jurídico independente e auxiliar ao negócio jurídico a concluir ou concluído. É independente por ter suporte fático próprio quanto à existência, validade e eficácia do negócio jurídico a concluir ou concluído. É auxiliar por ser elemento complementar à validade ou à eficácia do negócio jurídico a ser auxiliado.

3) Esse negócio jurídico independente e auxiliar pode ser prévio, contemporâneo ou posterior ao negócio jurídico principal.

4) As características apresentadas por essa declaração de vontade compõem assentimento a negócio jurídico de outrem. Essa figura jurídica apresenta um caráter geral a compor, à luz do Código Civil, a existência no sistema jurídico brasileiro da teoria geral do assentimento. 5) O assentimento a negócio jurídico de outrem é imposto pelo ordenamento para determinados negócios jurídicos, visando à proteção de interesses jurídicos. Em razão do interesse protegido, há o assentimento vigilante e o assentimento autointeressado. $\mathrm{O}$ assentimento vigilante tem por função proteger interesse de um dos figurantes de um negócio jurídico. O assentimento autointeressado tem por função proteger interesse do próprio assentiente.

6) O assentimento é a declaração de vontade por intermédio da qual determinado sujeito de direito assente para que o negócio jurídico a concluir ou concluído por outrem, a depender do suporte fático legal, seja válido ou eficaz.

7) Como fato jurídico, o assentimento pode ser classificado como negócio jurídico unilateral, receptício e causal.

8) Quanto à existência do negócio jurídico a ser assentido, há o assentimento prévio prestado antes de ser concluído o negócio jurídico assentido - e o assentimento posterior, prestado depois de ser concluído o negócio jurídico assentido.

9) O assentimento prévio, em razão da nomenclatura empregada no Código Civil, se depreende na expressão "autorização prévia". O assentimento posterior, ao contrário, se 
depreende, na expressão empregada no Código Civil, "autorização posterior", que, em verdade, é a figura jurídica da aprovação.

10) A aprovação não se confunde com a ratificação. Esta é figura jurídica vinculada ao instituto da representação, pois torna eficaz o negócio jurídico concluído por terceiro, em nome do ratificante, mas sem poderes de representação. O ratificante não é terceiro a assentir com o negócio jurídico concluído pelo falso procurador, mas o próprio figurante, não sendo a ratificação figura pertencente à teoria geral do assentimento.

11) Pela eficácia da autorização, atribui-se ao autorizado ou faculdade para concluir negócio jurídico ou poder para dispor de direito alheio, em nome próprio - o que, por consectário, gera ao autorizado a legitimidade para exercer posição jurídica ativa.

12) A autorização integrativa é negócio jurídico unilateral com a eficácia de atribuir faculdade jurídica ao autorizado e, secundariamente, afastar limitação ao exercício da autonomia privada à conclusão de negócio jurídico válido ou eficaz.

13) A autorização integrativa, a depender da situação jurídica, é passível de revogação.

14) A autorização integrativa não pode ser confundida com a figura jurídica da permissão. Embora ambas apresentem igual eficácia jurídica — atribuir faculdade e, secundariamente, afastar limitação ao exercício da autonomia privada —, a permissão não decorre de declaração de vontade de terceiro, mas de figurante inserto na parte de negócio jurídico.

15) A autorização para dispor é negócio jurídico unilateral com a eficácia de atribuir ao autorizado o poder para dispor direito do autorizante, em nome próprio, com eficácia direta sobre a esfera do titular.

16) Como fundamentos legais à existência da autorização para dispor, estão, no direito privado brasileiro, os suportes fáticos relativos ao contrato estimatório (art. 534) e ao contrato de comissão para venda (art. 693).

17) A autorização para dispor, a depender da situação jurídica, é revogável.

18) Não há, no sistema jurídico interno, fundamento legal para se admitir, pela figura da autorização para dispor, ao contrário do direito alemão, a existência da autorização para cobrar, da autorização para contrair obrigação e da autorização para adquirir. 


\section{BIBLIOGRAFIA}

ADAMEK, Marcelo Vieira von. Responsabilidade civil dos administradores de S/A e ações correlatas. São Paulo: Saraiva, 2009.

AGUIAR JÚNIOR, Ruy Rosado de. Comentários ao novo Código Civil: da extinção do contrato. Coord. Sálvio de Figueiredo Teixeira. Rio de Janeiro: Forense, 2011, v. 6, t. 2.

ALBUQUERQUE, Pedro. A representação voluntária em direito civil: ensaio de reconstrução dogmática. Coimbra: Almedina, 2004.

ANDRADE NERY, Rosa Maria de; NERY JÚNIOR, Nelson. Código Civil comentado. 11. ed. São Paulo: Revista dos Tribunais, 2014.

_ _ _ Instituições de direito civil: parte geral. São Paulo: Revista dos Tribunais, 2015, v. I t. II.

ASSIS, Araken. Contratos nominados: mandato, comissão, agência e distribuição, corretagem, transporte. São Paulo: Revista dos Tribunais, 2005.

ASTONE, Antonino. Contratto Negozio Regolamento: contributo allo studio del negozio unilaterale. Milano: Giuffrè, 2008.

AURICCHIO, Alberto. Autorizzazione (dir. priv.). Enciclopedia del diritto. Milano: Giuffrè, 1959, v. IV, p. 502-508.

ÁVILA, Humberto. Teoria da segurança jurídica. 4. ed. São Paulo: Malheiros, 2016.

. Teoria dos princípios: da definição à aplicação dos princípios jurídicos. 17. ed.

São Paulo: Malheiros, 2016.

AZEVEDO, Antônio Junqueira de. Negócio jurídico e declaração negocial: noções gerais e formação da declaração negocial. São Paulo: [s.e.], 1986.

Negócio jurídico: existência, validade e eficácia. São Paulo: Saraiva, 2002.

AZEVEDO, Francisco Ferreira dos Santos. Dicionário analógico da língua portuguesa: ideias afins/thesaurus. 2. ed. Rio de Janeiro: Lexikon, 2010.

BARBOSA, Ruy. Parecer sobre a redação do Código Civil. Obras completas de Rui Barbosa. Rio de Janeiro: Imprensa Nacional, 1949, v. XXIX, t. I.

BDINE JR., Hamid Charaf. Cessão de posição contratual. 2. ed. São Paulo: Saraiva, 2008. 
BENEDETTI, Giuseppe. Dal contratto al negozio unilaterale. Milano: Giuffrè, 2007.

BETTI, Emílio. Teoria geral do negócio jurídico. Trad. Fernando de Miranda. Coimbra: Coimbra, 1969, t. II.

. Teoria geral do negócio jurídico. Trad. Fernando de Miranda. Coimbra: Coimbra, 1970 , t. III.

BEVILÁQuA, Clóvis. Código Civil dos Estados Unidos do Brasil comentado. 11. ed. atual. Achilles Bevilaqua e Isaias Bevilaqua. Rio de Janeiro: Francisco Alves, 1956, v. I.

BIGIAVI, Walter. La delegazione. Padova: Cedam, 1940.

BUENO, Francisco da Silveira. Grande dicionário etimológico-prosódico da língua portuguesa. Saraiva: São Paulo, 1963, v. 1.

CABRAL, Antonio da Silva. Cessão de contratos. São Paulo: Saraiva, 1987.

CALDENTEY, J. Ladaria. Legitimación y apariencia jurídica. Barcelona: Bosch, 1952.

CANARIS, Claus-Wilhelm. Funções da parte geral de um código civil e limites da sua prestabilidade. Revista da AJURIS/Associação dos Juizes do Rio Grande do Sul. Porto Alegre: Ajuris, n. 95, 2004, p. 271-286.

CANDIAN, Aurelio. Atto autorizzato, atto materiale lecito, atto tollerato: contributo alla teoria dell'atto giuridico. Saggi di diritto. Milano: Giuffrè, 1949, v. III, 229-259.

CARIOTA FERRARA, Luigi. Il negozio giuridico nel diritto privato italiano. Napoli: Edizioni Scientifiche Italiane, 2011.

CARRARO, Luigi. Approvazione. Enciclopedia del diritto. Milano: Giuffrè, 1958, v. II, p. $852-855$.

. Autorizzazione. Novissimo digesto italiano. Torino: UTET, 1958, v. 1/2, p. 1577 1580.

. Contributo alla dottrina dell'autorizzazione. Rivista trimestrale di diritto $e$ procedura civile. Milano: Giuffrè, 1947, anno I, p. 282-314.

. Dichiarazione recettizia. Novissimo digesto italiano. Torino: UTET, 1960, v. V, p. 597-599.

CARRIÓ, Genaro R. Notas sobre derecho y lenguaje. 3. ed. Buenos Aires: AbeledoPerrot, 1986. 
CARVALHO DE MENDONÇA, José Xavier. Tratado de direito commercial brasileiro. 2. ed. rev. por Achilles Bevilaqua e Roberto Carvalho de Mendonça. Rio de Janeiro: Freitas Bastos, 1934, v. VI, parte I.

CARVALHO SANTOS, João Manuel de. Código Civil brasileiro interpretado. 7. ed. Rio de Janeiro: Freitas Bastos, 1958, v. III.

CASTRO, Torquato. Teoria da situação jurídica em direito privado nacional. São Paulo: Saraiva, 1985.

CAVALCANTI, José Paulo. Direito civil: escritos diversos. Rio de Janeiro: Forense, 1983. CESAR, Dimas de Oliveira. Estudo sobre a cessão do contrato. São Paulo: Revista dos Tribunais, 1954.

COING, Helmut. Elementos fundamentais da filosofia do direito. Trad. Elisete Antoniuk. Porto Alegre: Sergio Antonio Fabris, 2002.

COLLAÇO, Isabel Maria Tello de Magalhães. Da legitimidade no acto jurídico. Boletim do Ministério da Justiça. Lisboa: Gabinete de Documentação e Direito Comparado da Procuradoria Geral da República, 1949, v. 10, p. 20-112.

COMPARATO, Fábio Konder. Eficácia dos acordos de acionista. Novos ensaios e pareceres de direito empresarial. Rio de Janeiro: Forense, 1981, p. 74-87.

. Notas sobre parte e legitimação nos negócios jurídicos. Ensaios e pareceres de direito empresarial. Rio de Janeiro: Forense, 1978. p. 513-520.

COUTO E SILVA, Clóvis do. Cessão de crédito. Revista dos Tribunais. São Paulo: Revista dos Tribunais, 1988, v. 638, p. 10-14.

. Para uma história dos conceitos no direito civil e no direito processual civil (a atualidade do pensamento de Otto Karlowa e de Oskar Bülow). Revista de Processo. São Paulo: Revista dos Tribunais, 1985, v. 37, p. 238-270.

CUNHA, Antônio Geraldo da. Dicionário etimológico da língua portuguesa. 4. ed. Rio de Janeiro: Lexikon, 2010.

D’AVANZO, Walter. Rappresentanza (diritto civile). Novissimo digesto italiano. Milano: UTET, 1967, v. XIV, p. 800-832.

DEL NERO, João Alberto Schützer. Considerações sobre a eficácia do registro, efetuado em registro público material e territorialmente competente, de negócios jurídicos de 
obrigação e de certos negócios jurídicos de disposição (cessão de crédito; constituição de penhor comum, especial, de crédito e de título de crédito; constituição de propriedade fiduciária de coisa móvel, infungível ou fungível; constituição de titularidade fiduciária de direito e de título de crédito). Revista de direito mercantil, industrial, econômico e financeiro. São Paulo: Malheiros, ano LIII, ago. 2013/jul. 2014, n. 166/167, p. 219-271.

DELGADO, José Augusto. Comentários ao Código Civil brasileiro: dos fatos jurídicos. Coord. Arruda Alvim e Thereza Alvim. Rio de Janeiro: Forense, 2008, v. 2.

DIAS, Adahyl Lourenço. Venda a ascendente. 2. ed. Rio de Janeiro: José Konfino, p. 1976.

DÍEZ-PICAZO, Luis. Experiencias jurídicas y teoría del derecho. 3. ed. Barcelona: Ariel, 1993.

DINIZ, Maria Helena. Curso de direito civil brasileiro: teoria das obrigações contratuais e extracontratuais. 21. ed. São Paulo: Saraiva, 2005.

DONISI, Carmine. Il contrato con se stesso. Napoli: Edizioni Scientifiche Italiane, 2002.

Emendas do Senado ao Projecto da Camara, n. 1, de 1902 do Código Civil Brazileiro, com Parecer da Commissão Especial. Rio de Janeiro: Imprensa Nacional, 1913.

ENGISCH, Karl. Introdução ao pensamento jurídico. Trad. João Baptista Machado. 7. ed. Lisboa: Calouste Gulbenkian, 1996.

ENNECCERUS, Ludwig; NIPPERDEY, Hans Carl. Derecho civil: parte general. In: ENNECCERUS, Ludwig; KIPP, Theodor; WOLF, Martin. Tratado de derecho civil. Trad. Blas Pérez González y José Alguer. 3. ed. Barcelona: Bosch, 1981, t. I, v. II - primeira parte.

. In: ENNECCERUS, Ludwig; KIPP, Theodor; WOLF, Martin. Tratado de derecho civil. Trad. Blas Pérez González y José Alguer. 3. ed. Barcelona: Bosch, 1981, t. I, v. II - segunda parte.

ESPINOLA, Eduardo; ESPINOLA FILHO, Eduardo. Tratado de direito civil brasileiro. Rio de Janeiro: Freitas Bastos, 1941, t. IX.

ESPINOLA, Eduardo. Parte geral: dos factos juridicos. Manual do Código Civil brasileiro. Org. Paulo de Lacerda. Rio de Janeiro: Jacintho Ribeiro dos Santos, 1923, v. III, parte primeira. 
FALZEA, Angelo. Capacità (teoria gen.). Enciclopedia del diritto. Milano: Giuffrè, 1960, v. VI, p. 8-47.

FARINA, Vicenzo. L'autorizzazione a disporre in diritto civile. Napoli: Edizioni Scientifiche Italiane, 2001.

FERRARA, Luigi Cariota. Il negozio sul patrimonio altrui. Napoli: Edizioni Scientifiche Italiane, 2011.

FERREIRA, Roberto Schaan. Cisão entre direito subjetivo pretensão (ação). Estudos jurídicos. São Leopoldo: UNISINOS, 1991, v. 24, n. 61, p. 37-49.

FERREIRA, Waldemar. Tratado de direito comercial. São Paulo: Saraiva, 1960, v. 2.

FERRI, Giovanni Battista. Parte del negozio. Enciclopedia del diritto. Giuffrè: Milano, 1981, v. XXXI, p. 901-916.

FIGUEIREDO, Cândido de. Dicionário da língua portuguesa. 24. ed. Lisboa: Bertrand, 1991, v. I.

FLUME, Werner. El negocio jurídico: parte general del derecho civil. Trad. José María Miquel González y Esther Gómez Calle. Madrid: Fundación Cultural del Notariado, 1998.

FRADERA, Véra Maria Jacob de. O valor do silêncio no novo Código Civil. Aspectos controvertidos do novo Código Civil: escritos em homenagem ao Ministro José Carlos Moreira Alves. São Paulo: Revista dos Tribunais, 2003, p. 569-582.

FREIRE, Laudelino. Grande e novíssimo dicionário da língua portuguesa. 2. ed. Rio de Janeiro: José Olympio, 1954, v. I.

2. ed. Rio de Janeiro: José Olympio, 1954, v. V.

GAINO, Itamar. Invalidade do negócio jurídico. Teoria geral do direito civil. Coord. Renan Lotufo e Giovanni Ettore Nanni. São Paulo: Atlas, 2008, p. 633-700.

GALGANO, Francesco. Il negozio giuridico. 2. ed. Trattato di diritto civile e commerciale. Milano: Giuffrè, 2002.

GASPARRI, Pietro. Autorizzazione (dir. amm.). Enciclopedia del diritto. Milano: Giuffrè, 1959, v. IV, p. 509-516.

GERI, Lina Bigliazzi. Procura. Enciclopedia del diritto. Milano: Giuffrè, 1987, v. XXXVI, p. 995-1011. 
GIAMPICCOLO, Giorgio. Dichiarazione recettizia. Enciclopedia del diritto. Milano: Giuffrè, 1964, v. XII, p. 384-391.

GOMES, Orlando. Contratos. 6. ed. Rio de Janeiro: Forense, 1977. . Introdução ao direito civil. 10. ed. Rio de Janeiro: Forense, 1988.

. Venda sem autorização da assembleia de S.A. Novas questões de direito civil. São Paulo: Saraiva, 1979, p. 205-215.

GONÇALVES, Carlos Roberto. Direito civil brasileiro: contratos e atos unilaterais. 7. ed. São Paulo: Saraiva, 2010, v. 3.

GONDIM, Regina. Invalidade do testamento. Rio de Janeiro: Renovar, 2001.

GONZÁLEZ, Blas Pérez. ALGUER, José. GETE-ALONSO, Maria del Carmen. Notas. In: ENNECCERUS, Ludwig; KIPP, Theodor; WOLF, Martin. Tratado de derecho civil. Trad. Blas Pérez González y José Alguer. 3. ed. Barcelona: Bosch, 1981, t. I, v. II - segunda parte.

GOZZO, Débora. Ação de nulidade de venda a ascendente. São Paulo: 1988.

. Assentimento de terceiro e negócio jurídico: análise comparativa entre os direitos brasileiro e alemão. Revista do Instituto dos Advogados de São Paulo. São Paulo: Revista dos Tribunais, 2007, n. 20, p. 66-79.

GRAU, Eros Roberto. Por que tenho medo dos juizes: a interpretação/aplicação do direito e os princípios. 6. ed. refundida do ensaio e discurso sobre a interpretação/aplicação do direito. São Paulo: Malheiros, 2013.

GRAZIANI, Alessandro. La cessione dei crediti. Studi di diritto civile e commerciale. Napoli: Jovene, 1953, p. 151-238.

. Sul mandato senza rappresentanza. Studi di diritto civile e commerciale. Napoli: Jovene, 1953, p. 100-108.

GUASTINI, Riccardo. Interpretare e argomentare. Trattato di diritto civile e commerciale. Milano: Giuffrè, 2011.

HAFT, Fritjof. Direito e linguagem. Introdução à filosofia do direito e à teoria do direito contemporâneas. Org. Arthur Kaufmann e Winfried Hassemer. Trad. Marcos Keel e Manuel Seca de Oliveira. Rev. e coord. António Manuel Hespanha. 3. ed. Lisboa: Calouste Gulbenkian, 2015, p. 303-326. 
HERNÁNDEZ, Francisco Rivero. Representación sin poder y ratificación. Pamplona: Civitas, 2013.

HOUAISS, Antonio; VILlAR, Mauro de Salles. Dicionário Houaiss da língua portuguesa. Rio de Janeiro: Objetiva, 2009.

HUPKA, Josef. La representación voluntaria en los negocios jurídicos. Trad. Luis Sancho Seral. Madrid: Revista de Derecho Privado, 1930.

JUSTEN FILHO, Marçal. Curso de direito administrativo. 9. ed. São Paulo: Revista dos Tribunais, 2013.

KAUFMANN, Arthur. Filosofia do direito. Trad. António Ulisses Cortês. 5. ed. Lisboa: Calouste Gulbenkian, 2014.

KELSEN, Hans. Teoria geral das normas. Trad. José Florentino Duarte. Porto Alegre: Sergio Antonio Fabris, 1986.

KROETZ, Maria Cândida do Amaral. A representação voluntária no direito privado. São Paulo: Revista dos Tribunais, 1997.

LACERDA, Galeno. Cessão de crédito e legitimação no sistema bancário. Revista dos Tribunais. São Paulo: Revista dos Tribunais, 1989, v. 644, p. 427-432.

LARENZ, Karl. Derecho civil: parte general. Trad. Miguel Izquierdo y Macías-Picavea. Madrid: EDERSA, 1978.

Metodologia da ciência do direito. Trad. José Lamego. 3. ed. Lisboa: Calouste Gulbenkian, 1997.

LENER, Angelo. Potere (dir. priv.). Enciclopedia del diritto. Milano: Giuffrè, 1985, v. XXXIV, p. 610-642.

LÔBO, Paulo Luiz Netto. Comentários ao código civil: parte especial - das várias espécies de contrato. Coord. Antônio Junqueira de Azevedo. São Paulo: Saraiva, 2003, v. 6.

LOTUFO, Renan. Código Civil comentado: contratos em geral até doação. São Paulo: Saraiva, 2016, v. 3, t. I.

. Código Civil comentado: parte geral. 3. ed. São Paulo: Saraiva, 2016, v. 1. Questões relativas a mandato, representação e procuração. São Paulo: Saraiva, 2001. 
LUMIA, Giuseppe. Lineamenti di teoria e ideologia del diritto. 3. ed. Milano: Giuffrè, 1981.

LUMINOSO, Angelo. Mandato, Commissione, Spedizione. Trattato di diritto civile e commerciale. Milano: Giuffrè, 1984, v. XXXII.

LUZZATI, Claudio. La vaghezza delle norme: un'analisi del linguaggio giuridico. Milano: Giuffrè, 1990.

MACHADO, João Baptista. Tutela da confiança e venire contra factum proprium. Obra dispersa. Braga: Scientia Ivridica, 1991, v. I, p. 345-423.

MAIA JÚNIOR, Mairan Gonçalves. A representação no negócio jurídico. 2. ed. São Paulo: Revista dos Tribunais, 2004.

MAJO, Adolfo di. Legittimazione negli atti giuridici. Enciclopedia del diritto. Milano: Giuffrè, 1974, v. XXIV, p. 52-65.

MANES, Humberto de Mendonça. A legitimação negocial: premissas básicas. Rio de Janeiro: Liber Juris, 1982.

MARTINS-COSTA, Judith. Autoridade e utilidade da doutrina: a construção dos modelos doutrinários. Modelos de direito privado. Org. Judith Martins-Costa. São Paulo: Marcial Pons, 2014, p. 9-32.

. Negócio jurídico de assunção de dívida: algumas notas. Revista Jurídica InPactum. Recife: Fundação Antônio dos Santos Abranches, 2011, n. 7, p. 158-170.

. O novo código civil brasileiro: em busca da "ética da situação". MARTINSCOSTA, Judith; BRANCO, Gerson. Diretrizes teóricas do novo Código Civil brasileiro. São Paulo: Saraiva, 2002, p. 87-168.

MASSIMO BIANCA, Cesare. Diritto civile: il contratto. Milano: Giuffrè, 1998, v. 3.

MAXIMILIANO, Carlos. Hermenêutica e aplicação do direito. 3. ed. Rio de Janeiro: Freitas Bastos, 1941.

MELLO, Celso Antônio Bandeira de. Curso de direito administrativo. 30. ed. São Paulo: Malheiros, 2013.

MELLO, Marcos Bernardes de. Teoria do fato jurídico: plano da eficácia - $1^{\mathrm{a}}$ parte. 2. ed. São Paulo: Saraiva, 2004. . Teoria do fato jurídico: plano da existência. 12. ed. São Paulo: Saraiva, 2003. 
. Teoria do fato jurídico: plano da validade. 6. ed. São Paulo: Saraiva, 2004.

MELO, Tânia S. P. de Campos. Contrato estimatório: autonomia no direito moderno. Estudos jurídicos em homenagem ao professor Caio Mário da Silva Pereira. Rio de Janeiro: Forense, 1984, p. 592-620.

MENEZES CORDEIRO, António. Tratado de direito civil: direito das obrigações. 2. ed. Coimbra: Almedina, 2012, v. VI.

. Tratado de direito civil: parte geral. 2. ed. Coimbra: Almedina, 2015, v. V.

MENGONI, Luigi; REALMONTE, Francesco. Disposizione (atto di). Enciclopedia del diritto. Milano: Giuffrè, 1964, v. XIII, p. 189-194.

MESSINEO, Francesco. Contratto (dir. priv.). Enciclopedia del diritto. Milano: Giuffrè, 1961, v. IX, p. 784-979.

MINERVINI, Gustavo. Il mandato, la commissione, la spedizione. Trattato di diritto civile italiano. Torino: UTET, 1954, v. 8, t. I.

MIRABELLI, Giuseppe. L'atto non negoziale nel diritto privato italiano. Napoli: Jovene, 1955.

MONACCIANI, Luigi. Azione e legittimazione. Milano: Giuffrè, 1951.

MORA, José Ferreter. Diccionario de filosofia. 3. ed. Madrid: Alianza, 1981, t. 3.

MORAES, Bernardo B. Queiroz de. Parte geral: código civil: gênese, difusão e conveniência de uma ideia. São Paulo: YK, 2018.

MOREIRA ALVES, José Carlos. 10a reunião - Conferência do Professor Ministro Moreira Alves. Código Civil brasileiro no debate parlamentar: elementos históricos da elaboração da Lei $n^{\circ}$ 10.406, de 2002. Org. José Theodoro Mascarenhas Menck. Brasília: Câmara dos Deputados, 2012, v. 1, t. 1, p. 411-460.

- A parte geral do projeto de Código Civil brasileiro (subsídios históricos para o novo Código Civil brasileiro). 2. ed. São Paulo: Saraiva, 2003.

- Considerações sobre a disciplina do negócio jurídico consigo mesmo no novo Código Civil brasileiro. Revista do Advogado. São Paulo: AASP, 2008, n. 98, p. 7-11.

. Distinção entre os atos jurídicos negociais e os atos jurídicos não-negociais. Revista da Academia Brasileira de Letras Jurídicas. Rio de Janeiro: Academia Brasileira de Letras Jurídicas, 1996, v. 10, p. 170-189. 
. Posse: estudo dogmático. 2. ed. Rio de Janeiro: Forense, 1999, v. II, t. I.

MOSCO, Luigi. La rappresentanza volontaria nel diritto privato. Napoli: Jovene, 1961.

MOTA PINTO, Carlos Alberto da. Cessão de contrato: contendo parte tratando a matéria conforme o direito brasileiro. São Paulo: Saraiva, 1985.

. Teoria geral do direito civil. 4. ed. atual. por António Pinto Monteiro e Paulo Mota Pinto. Coimbra: Coimbra, 2005.

MOTA PINTO, Paulo. Interesse contratual negativo e interesse contratual positivo. Coimbra: Coimbra, 2008, v. I.

NASCENTES, Antenor. Dicionário etimológico da língua portuguesa. Rio de Janeiro: Francisco Alves, 1955, t. I.

NATOLI, Ugo. La rappresentanza. Milano: Giuffrè, 1977.

NATTINI, Angelo. Il negozio autorizzativo. Rivista del diritto commerciale e del diritto generale delle obbligazioni. Milano: Dottor Francesco Vallardi, 1912, v. X, parte prima, p. 485-491.

. La dottrina generale della procura: la rappresentanza. Milano: Società Editrice Libraria, 1910.

NEGRÃO, Ricardo. Manual de direito comercial e de empresa: títulos de crédito e contratos empresariais. São Paulo: Saraiva, 2010, v. 2.

NETO, Manoel Severo. Teoria da legitimação. São Paulo: Juarez de Oliveira, 2009.

NETO, Soriano. A construção científica alemã sobre os atos jurídicos em sentido estrito e a natureza jurídica do reconhecimento da filiação ilegítima. Revista Acadêmica. Recife: Anais da Universidade do Recife, 1957, ano LVIII (1951-1956), p. 8-30.

NOVAES FRANÇA, Erasmo Valladão Azevedo e. ADAMEK, Marcelo Vieira Von. Vinculação da sociedade: análise crítica do art. 1.015 do Código Civil. In: NOVAES FRANÇA, Erasmo Valladão Azevedo e. Temas de direito societário, falimentar e teoria da empresa. São Paulo: Malheiros, 2009, p. 147-172.

. Ilegitimidade de parte e falta de interesse processual da companhia para requerer a anulação das próprias deliberações. Temas de direito societário, falimentar e teoria da empresa. São Paulo: Malheiros, 2009, p. 378-400. 
. Invalidade das deliberações de assembleia de $S / A$ e outros escritos sobre o tema da invalidade das deliberações sociais. 2. ed. São Paulo: Malheiros, 2017.

NUNES, Pedro dos Reis. Dicionário de tecnologia jurídica. 12. ed. Rio de Janeiro: Freitas Bastos, 1990.

OERTMANN, Paul. Introducción al derecho civil. Trad. Luis Sancho Seral. Barcelona: Labor, 1933.

OLIVA, Rocío Diéguez. Eficacia real y obligacional de la representación indirecta. Valencia: Tirant lo Blanch, 2006.

PANE, Rosanna. Solidarietà sociale e gestione di affari altrui. Napoli: Edizioni Scientifiche Italiane, 1996.

PANUCCIO, Vincenzo. Le dichiarazioni non negoziali di volontà. Milano: Giuffrè, 1966.

PENTEADO, Luciano de Camargo. Efeitos contratuais perante terceiros. São Paulo: Quartier Latin, 2007.

PENTEADO, Mário de Salles. A legitimação nos atos jurídicos. Revista dos Tribunais. São Paulo: Revista dos Tribunais, 1973, v. 454, p. 26-35.

PESSOA ALVES, Francisco Glauber et al. Comentários ao Código Civil brasileiro: do direito das obrigações. Coord. Arruda Alvim e Thereza Alvim. Rio de Janeiro: Forense, 2007, v. 5 .

PESSOA JORGE, Fenando de Sandy Lopes. O mandato sem representação. Coimbra: Almedina, 2001.

PLÁCIDO E SILVA, Oscar Josef de. Vocabulário jurídico. Rio de Janeiro: Forense, 1967, v. I.

. Rio de Janeiro: Forense, 1967, v. III.

POMPEU, Cid Tomanik. Autorização administrativa. 3. ed. São Paulo: Revista dos Tribunais, 2009.

PONTES DE MIRANDA, Francisco Cavalcanti. Comentários à constituição de 1946. 3. ed. Rio de Janeiro: Borsoi, 1960, t. II.

. Comentários ao Código de Processo Civil. 2. ed. Rio de Janeiro: Forense, 1979, t.

I. 
. Garra, mão e dedo. Campinas: Bookseller, 2002.

. Parecer n. 145: sobre perda de eficácia de declarações de vontade testamentárias. Questões forenses. Rio de Janeiro: Borsoi, 1958, t. III, p. 422-424.

. Parecer n. 278: sobre procuração de cônjuge ao outro cônjuge para venda de imóveis, e venda, com os poderes de representação, à pessoa jurídica de que é órgão o representado. Dez anos de pareceres. Rio de Janeiro: Francisco Alves, 1977, v. 10, p. 355370.

. Sistema de ciência positiva do direito. Campinas: Bookseller, 2000, t. II.

. Tratado das ações. São Paulo: Revista dos Tribunais, 1971, t. II.

. Tratado de direito privado. 4. ed. São Paulo: Revista dos Tribunais, 1983, t. I.

. 4. ed. São Paulo: Revista dos Tribunais, 1983, t. II.

. 4. ed. São Paulo: Revista dos Tribunais, 1983, t. III.

.4. ed. São Paulo: Revista dos Tribunais, 1983, t. IV.

. 4. ed. São Paulo: Revista dos Tribunais, 1983, t. V.

. 4. ed. São Paulo: Revista dos Tribunais, 1983, t. VI.

. 4. ed. São Paulo: Revista dos Tribunais, 1983, t. VIII.

. 4. ed. São Paulo: Revista dos Tribunais, 1983, t. X.

. 4. ed. São Paulo: Revista dos Tribunais, 1983, t. XI.

. 4. ed. São Paulo: Revista dos Tribunais, 1983, t. XV.

. 3. ed. São Paulo: Revista dos Tribunais, 1984, t. XXIII.

. 3. ed. São Paulo: Revista dos Tribunais, 1984, t. XXXI.

. 3. ed. São Paulo: Revista dos Tribunais, 1984, t. XXXVIII.

. 3. ed. São Paulo: Revista dos Tribunais, 1984, t. XXXIX.

. 3. ed. São Paulo: Revista dos Tribunais, 1984, t. XL.

. 3. ed. São Paulo: Revista dos Tribunais, 1984, t. XLII.

3. ed. São Paulo: Revista dos Tribunais, 1984, t. XLIII.

. 3. ed. São Paulo: Revista dos Tribunais, 1984, t. L. 
. 3. ed. São Paulo: Revista dos Tribunais, 1984, t. LIII.

. 3. ed. São Paulo: Revista dos Tribunais, 1984, t. LVII.

PRADO E SILVA, Adalberto et al. Dicionário brasileiro da língua portuguesa. 2. ed. São Paulo: Mirador Internacional, 1977.

Projecto do Código Civil Brazileiro: trabalhos da comissão especial da Camara dos Deputados - projeto primitivo e revisto. Rio de Janeiro: Imprensa Nacional, 1902.

PUGLIATTI, Salvatore. Esercizio del diritto (dir. priv.). Enciclopedia del diritto. Milano: Giuffrè, 1966, v. XV, p. 622-627.

REALE, Miguel. Fontes e modelos do direito: para um novo paradigma hermenêutico. São Paulo: Saraiva, 1999.

. História do novo Código Civil. São Paulo: Revista dos Tribunais, 2005. . Lições preliminares de direito. 24. ed. São Paulo: Saraiva, 1998.

RESCIGNO, Pietro. Legittimazione (diritto sostanziale). Novissimo digesto italiano. Torino: UTET, 1963, v. IX, p. 716-721.

RIZZARDO, Arnaldo. Contratos. 3. ed. Rio de Janeiro: Forense, 2004.

. Parte Geral do Código Civil. 3. ed. Rio Janeiro: Forense, 2005.

RODRIGUES JUNIOR, Otavio Luiz. A doutrina do terceiro cúmplice: autonomia da vontade, o res inter alios acta, função social do contrato e a interferência alheia na execução dos negócios jurídicos. Revista dos Tribunais. São Paulo: Revista dos Tribunais, 2004, v. 821, p. 80-98.

. Código Civil comentado: compra e venda, troca, contrato estimatório - arts. 481 a 537. Coord. Álvaro Villaça Azevedo. São Paulo: Atlas, 2008, v. VI, t. I.

ROMANO, Francesco. La ratifica nel diritto privato. Napoli: Morano, 1964.

SAGGESE, Francesco. La rappresentanza nella teoria e nella pratica del diritto privato italiano. Napoli: Jovene, 1933.

SANSEVERINO, Paulo de Tarso Vieira. Contratos nominados II: contrato estimatório, doação, locação de coisas, empréstimo (comodato - mútuo). São Paulo: Revista dos Tribunais, 2005. 
SANTORO-PASSARELLI, Francesco. Dottrine generali del diritto civile. 9. ed. Napoli: Jovene, 1981.

SARAIVA, F. R. dos Santos. Novissimo diccionario latino-portuguez: etymologico, prosódico, histórico, geográfico, mythologico, biográfico, etc.. Rio de Janeiro: B. L. Garnier, [s.d.], v. I.

SCARPELLI, Uberto. Semantica giuridica. Novissimo digesto italiano. Torino: UTET, 1969, v. XVI, p. 978-999.

SCHLESINGER, Piero. Il pagamento al terzo. Milano: Giuffrè, 1961.

SCHMIDT, Karsten. Derecho comercial. Trad. Federico E. G. Werner. Buenos Aires: Astrea, 1997.

SILVA PEREIRA, Caio Mário. Instituições de direito civil: contratos. 11. ed. rev. e atual. por Regis Fichtner. Rio de Janeiro: Forense, 2005, v. III.

. Comentários ao código civil de 2002: parte geral arts. $1^{\circ}$ a 232. Atualiz. Cristiano de Souza Zanetti e Leonardo de Campos Melo. Rio de Janeiro: GZ, 2017.

SILVA, Antonio de Moraes. Diccionario da lingua portugueza. 8. ed. Rio de Janeiro: Empreza Litteraria Fluminense, 1889, v. I.

SIMÕES, Marcel Edvar. Transmissão em direito das obrigações: cessão de crédito, assunção de dívida e sub-rogação pessoal. São Paulo: Dissertação de mestrado na Faculdade de Direito da USP, 2011.

SOUZA, Sylvio Capanema de. Comentários ao novo Código Civil: das várias espécies de contrato, da troca ou permuta, do contrato estimatório, da doação, da locação de coisas. Coord. Sálvio de Figueiredo Teixeira. Rio de Janeiro: Forense, 2004, v. VIII.

SPINELLI, Luis Felipe. Conflito de interesses na administração da sociedade anônima. São Paulo: Malheiros, 2012.

SPITZER, Carlos. Dicionário analógico da língua portuguesa: tesouro de vocábulos e frases da língua portuguesa. 6. ed. Porto Alegre: Globo, 1957.

STANZIONE, Pasquale. Il soggetto: capacità, legittimazione, status. Trattato di diritto civile e commerciale. Milano: Giuffrè, 2017, v. II.

TAMPONI, Michele. L'atto non autorizzato nell'amministrazione dei patrimoni altrui. Milano: Giuffrè, 1992. 
TELLES JR., Goffredo da Silva. Autoridade - Autorização - Autorizar (Teoria geral do direito). Enciclopédia Saraiva do Direito. Coord. Rubens Limongi França. São Paulo: Saraiva, 1978, v. 9, p. 326-347.

. Autorizamento. Enciclopédia Saraiva do Direito. Coord. Rubens Limongi França. São Paulo: Saraiva, 1978, v. 9, p. 376-377. . Autorizante (Imperativo autorizante: definição de Norma Jurídica). Enciclopédia Saraiva do Direito. Coord. Rubens Limongi França. São Paulo: Saraiva, 1978, v. 9, p. $377-$ 392.

TEPEDINO, Gustavo; BARBOZA, Heloisa Helena; MORAES, Maria Celina Bodin. Código Civil interpretado conforme a Constituição da República. 2. ed. Rio de Janeiro: Renovar, 2007, v. I.

TEPEDINO, Gustavo. Comentários ao novo Código Civil: das várias espécies de contrato, do mandato, da comissão, da agência e distribuição, da corretagem, do transporte. Coord. Sálvio de Figueiredo Teixeira. Rio de Janeiro: Forense, 2008, v. X.

THEODORO JÚNIOR, Humberto. Comentários ao novo Código Civil: dos defeitos do negócio jurídico ao final do livro III. Rio de Janeiro: Forense, 2003, v. 3, t. 2.

THEODORO NETO, Humberto. Efeitos externos do contrato: direitos e obrigações na relação entre contratantes e terceiros. Rio de Janeiro: Forense, 2007.

THULLIER, Béatrice. L'autorisation: étude de droit privé. Paris: LGDJ, 1996.

TUHR, Andreas von. Derecho civil: teoría general del derecho civil alemán. Trad. Tito Ravá. Madrid: Marcial Pons, 2005, v. II.

: teoría general del derecho civil alemán. Trad. Tito Ravá. Madrid: Marcial Pons, 2005, v. III.

. Parte general del derecho civil. Trad. Wenceslao Roces. Granada: Comares, 2006.

TOMASETTI JR., Alcides et. al. Comentários à lei de locações de imóveis urbanos: Lei n. 8.245, de 18 de outubro de 1991. Coord. Juarez de Oliveira. São Paulo: Saraiva, 1992.

. A parte contratual. Temas de direito societário e empresarial contemporâneos. Coord. Marcelo Vieira von Adamek. São Paulo: Malheiros, 2011, p. 755-764. 
. A propriedade privada entre o Direito Civil e a Constituição. Estudos de direito civil, internacional privado e comparado: coletânea em homenagem à professora Véra Jacob de Fradera. Org. Leonardo Brandelli. São Paulo: Universitária de Direito, 2014, p. $19-25$.

. Comentário. Revista dos Tribunais. São Paulo: Revista dos Tribunais, v. 723, p. 208-223.

TORRINHA, Francisco. Dicionário português-latino. 2. ed. Porto: Domingos Barreira, [s.d.].

TUTIKIAN, Priscila David Sansone. O silêncio na formação dos contratos: proposta, aceitação e elementos da declaração negocial. Porto Alegre: Livraria do Advogado, 2009.

ULHOA COELHO, Fábio. Curso de direito civil. São Paulo: Saraiva, 2005, v. 3.

VANZELLA, Rafael Domingos Faiardo. O contrato e os direitos reais. São Paulo: Revista dos Tribunais, 2012.

VASCONCELOS, Pedro Leitão Pais de. A autorização. Coimbra: Coimbra, 2012.

VEIGA, Jorge. Legitimidade de parte no contrato. Recife: Mousinho, 1954.

VELOSO, Zeno. Invalidade do negócio jurídico: nulidade e anulabilidade. 2. ed. Belo Horizonte: Del Rey, 2005.

VENOSA, Sílvio de Salvo. Direito Civil: contratos em espécie. 5. ed. São Paulo: Atlas, 2005, v. 3 .

: parte geral. 8. ed. São Paulo: Atlas, 2008, v. I.

VERÇOSA, Haroldo Malheiros Duclerc. Direito comercial: os contratos empresariais em espécie (segundo a sua função jurídico-econômica). São Paulo: Revista dos Tribunais, 2014, v. 5.

VIEIRA NETO, Manoel Augusto. Ineficácia e convalidação do ato jurídico. São Paulo: Max Limonad, [s.d].

WESTERMANN, Harry. Código Civil alemão: parte geral. Trad. Luiz Dória Furquim. Porto Alegre: Sergio Antonio Fabris, 1991.

ZIPPELIUS, Reinhold. Teoria do método jurídico. Trad. António Franco e António Francisco de Sousa. 11. ed. São Paulo: Saraiva, 2016. 